\title{
Estimating a Function of Real Demand for Money in Pakistan: An Application of Bounds Testing Approach to Cointegration
}

\author{
Sober Mall \\ M.A. Economics (Pb), M.Phil Economics (Superior University), Lahore \\ Kashan-e-Dass, 9610 Ashwood Valley dr, Houston Tx. 77095, United States
}

\begin{abstract}
This paper attempts to model a real demand for money function of Pakistan. For this purpose we apply bounds test based cointegration technique using the time series data for the period 1973 to 2010. Our findings included three determinants: 1) real income and 2) foreign exchange contain positive relation as well as for both long run and short run dynamics they are the most significant factors of real demand for money. While we found real demand for money is negatively affected by 3) call money rate (is proxied by interest on deposit). However being in a short-run dynamic specification, money demand is found important with the elasticities of real income, exchange rate and call money rate being much smaller in the short-run than in long-run. Stability tests of the paper do not show any serious structural change in the model. As for both CUSUMSQ and CUSUM statistics, showing the critical value line within the bounds that present the model is stable. This model strongly recommends the real demand for $\mathrm{M} 2$ is an important monetary aggregate in terms of policy implications of our results including the suitability of the model in Pakistan.
\end{abstract}

\section{Keywords}

1) Real income 2) Foreign exchange rate 3) Call money rate 4) Call money rates 5) Interest rate 6) Autoregressive distributed lag (ARDL) 7) GDP deflator 8)

\section{INTRODUCTION}

A stable money demand function always requires an appropriate instruments and intermediate targets of monetary policy. It enables a policy driven change in monetary aggregates so that the desired values of targeted macroeconomic variables such as fiscal policy, exchange rate, stock market, consumption expenditure, saving, investment, imports, exports, inflation and interest rate are ensured. This pursuits to detect significant determinants of money demand since its instability is a major determinant of liquidity preference. These determinants have been witnessed and well studied by many researchers such as Friedman (1959), Adekunle (1968), Fry (1978), Gupta (1983), Johansen and Juselius (1990), Hafer and Jansen (1991), Hendry and Erricson (1991 a, b)) and Subramanain S. Sriram (1999).

For a stable money demand function attached with the economic growth also reveals several empirical studies at macroeconomic framework that conduct the profound contribution such as: Tobin (1958), Chow (1966), Goldfeld (1973), Judd and Scading (1982), Roley (1985), McCallum and Goods Friend (1987), Laidler (1990), Goldfeld and Sichel (1990), Taylor (1991) and much more, have left numerous of gaps which resourced a u-turn in the dimension of research again in order to find out if there are some microeconomic factors responsibly affecting the people hold cash balances with themselves. We have to focus on a deep analysis not only its macroeconomic grounds but its microeconomic foundations too Serletis, (2007).

Controlling the supply of money to its demand is always credited to an optimal monetary policy which facilitates an effective demand for money management as well as it also contributes to the achievement of price stability. A series studies on a stable demand for money function witness the effective monetary policies in advanced and industrialized countries. The studies based on the demand for money in these countries are especially characterized with the use of autoregressive distributed lag (ARDL) approach of cointegration Dr. Pervez Azim (2010). ARDL cointegration technique deals with a single cointegration equation as well as all the variables to be integrated in model are $\mathrm{I}(0)$ or $\mathrm{I}(1)$ or even both $I(0)$ and $I(1)$ integrated and it also provides robust results and super consistent estimates of the long-run coefficients in case of small samples Pesaran and Shin (1999). However most of developing countries are still using other techniques of cointegration but a few of them adopted this method such as Siddiki (2000), Mohsen Bahmani-Oskooee (2002), Muhammad Arshad Khan (2005), Sharifi-Renani (2007), Samreth, Sovannroeun (2008), Mahedhiran Nair (2008), Salvator CAPASO (2008), Rao, B. B. and Gazi Hassan, (2009), Noer Azam Achsani (2010), Dr. Pervez Azim, (2010), Prof. Nikolaos Dritsakis (2011), Nazar Dahmardeh (2011), Jihad Daghar (2011) and Hamid Raza Izadi (2011).

In a country like Pakistan, where monetary policy is affixed with alternations in monetary aggregates is used to remove the budgetary and balance of payment problems. It has been making the importance and need of real income, interest rate and exchange rate determinants since 1980 to identify a stable money demand function. A stable money demand function to stabilize the inflation rate helps the policy makers to forecast a change in output, rate of interest and price level as result of change in money supply Muhammad Arshad Khan, Muhammad Zabir Shahid (Winter 2005). According to Friedman (1956), most of the studies for a stable money demand function in advanced and industrialized countries used autoregressive distributed lag (ARDL) analysis. Whereas the economy of Pakistan and other developing countries in Asia have already gone through with several research papers contain an ARDL framework analysis. For instance: Muhammad Arshad Khan (2005) in Pakistan, Akinlo, A Enisan (2006) in Nigeria, Shari-Renani, Hosein (2007) in India, Rao, B. B. and Gazi Hassan (2009) in Bangladesh, Dr. Pervez Azim (2010) in Pakistan, Noer Azam Achsani (2010) in Indonesia, Jihad Daghar (2011) in Ghana, Nazar Dahmardeh and Hamid Raza Izadi (2011) in Iran, Prof. Nikolaos Dritsakis, (2011) in Hungary while some of research 
papers used Johansen Maximum Likelihood Test for Cointegration. For example: Bhattacharya (1995) in India, Qayyum (2001) in Pakistan, Jae-Kwang, Hwang (2002) in Korea, Qayyum (2005) in Pakistan, Reza Anglingkusumo (2005) in Indonesia, Tahir Mehmood (2005) in Pakistan, Qazi et al ,2009) in Pakistan. However several of them such as: Hossain, A. (1994) in Pakistan, D.V.G. Krishna (1996) in India, Khan and Ali (1997), Qayyum, A. (1998), Qayyum, A. $(2001,2005)$ in Pakistan, Samreth, Sovannroeun (2008) in Cambodia, Singh, Parakash and Pandey, Manoj K. (2009) in India, Noer Azam Achsani (2010) in Indonesia, Dr. Pervez Azim (2010) in Pakistan have adopted the provision of stability tests in their studies.

M2 demand functions established by Muhammad Arshad Khan, Muhammad Zabir Shahid (Winter 2005) and Qayyum (2005) in Pakistan were found to be stable functions with exception of Dr. Pervez Azim (2010). However to avoid the spurious relation among the demand for money (M2) and its determinants the researcher analyst considered auto regressive distributive lag (ARDL) cointegration approach for reliable results in the long-run as well as short-run equilibrium. For this sake we have taken price adjusted Broad Money (M2) "In Pakistan, three different types of monetary aggregates are in use to measure the stock of money as well as for policy formulation. These include the narrow measures M0, M1 and a broader aggregate M2. The M2 is composed of currency in circulation, other deposits with SBP, demand deposits, time deposits and Resident Foreign Currency Deposits (RFCDs) of the scheduled banks." (Monetary Aggregates in Pakistan; Mehmood-ul-Hasan Khan \& Fida Hussain).

Our study investigates the causality between real demand for money (Md), real income (Ry), Call money rates (CMR) as a proxy of interest rate on deposits and foreign exchange rates per UD dollar (ER) in Pakistan keeping in view several of research papers in case of Pakistan have found these determinants influence demand for money function significantly. Call money rate which is a proxy of interest rate refers a weak relation with the demand for money function. Whereas the exchange rate influenced as an important factor of money demand since floating exchange rate introduced in Pakistan has been causing the depreciation of a domestic currency from 1972 Depreciation of a domestic currency leaves an anti trusted behavior of the people on M1 demand for money which helps to increase the transactions of goods and services keeping the cash (M2) balance with the people. For example: Muhammad Arshad Khan, Muhammad Zabir Shahid (Winter 2005), Parez et al (2010). The relation between the demand for money (M2) and exchange rate in the developing countries have produced the mixed results. So to avoid the confusion different research papers justify the positive as well as the negative rationale of exchange rate with the demand for money (M2) in their model specification.

Money has no intrinsic value in the Classical economic system. The basis for money demand is merely to meet the transactional requirement of an individual. Therefore money acts as a "medium of exchange", the famous Fisher (1911) "equation of exchange" states that $\mathrm{MV}=\mathrm{PT}$ where $\mathrm{PT}=\mathrm{Price}$ multiplied by total no of Transactions (GDP) or PT=Nominal GDP and $\mathrm{M}$ is the quantity of Money and $\mathrm{V}$ is the velocity of money.

Thus under Classical system the nominal GDP depends upon the quantity of money and real GDP depends upon the production capacity of an economy. Therefore the central bank controls money supply and inflation completely.
Piguo (1917), Marshall, Alfred (1923) and other associated Cambridge Economists isolates the role of money supply to nominal income and undertakes the significance of money demand in shaping the role of monetary aggregates in price level. However the Neo-classicals do not pay much attention to the role of interest in the determination of money demand. According to them it is the future uncertainty that affects the Real Demand for Money (Laidler (1993), p.53).

Keynes, J. M, (1936) splits money demand into three types: transaction, speculation \& precaution. Accordingly in Keynes money demand the transaction demand serves as the "medium of exchange" function of money. The famous "Liquidity Trap" concept as presented by Keynes comes from his concept of speculative money demand. Moreover the "store of value" function of money is the central focus of speculative Real Demand for Money. Therefore Keynes formulation of Money Demand; $R M d=U(Y, i)$.

"The post Keynesian economists developed a number of models to provide the alternative explanations to confirm the formulation relating real money balances with real income and interest rates. The medium of exchange function of money led to the inventory -theoretic formulation that emphasized the transactions costs under certainty and to the precautionary Real Demand for Money models that introduced the concept of uncertainty in otherwise transaction cost model" (Subramanian S. Sriram ;1999).

The main purpose of this paper is to analyze the determinants of real demand for money in Pakistan applying an autoregressive distributive lag (ARDL) model. Other components of our study contain the following stages: Section II presents the literature review; section III reviews the econometric model and data resources. Empirical results are discussed in Section IV, Policy implications of findings are analyzed in Section V and finally section VI concludes the study.

\section{OBEJCTIVE}

The broad objective of the present work is to examine the role of real income, exchange rate and interest rate on deposits on money demand in Pakistan. The specific objectives of the study are set as follows:

1) To estimate a theoretical and empirical consistent model of Pakistani money demand function for the period 1973 to 2010, using the modern methodology of cointegration (ARDL) approach and its error correction modeling.

2) To evaluate money demand the behavior of Pakistani people in response of various macroeconomic changes in real income (real GDP), exchange rate and cost of holding money (interest rate on deposit). Although the theoretical literature taken from the previous studies real income was positively related with real demand for money. Real income is positively elastic with real demand for money has already been argued by Mohsen Bahmani-Oskooee (2002), Arshad khan (Winter 2005), Rehman (2005), Mohsen B, Charikleia E (2005), Renani (2007), Samreth, Sovannroeun (2008), Noer Azam Achsani (2010), Parez et al (2010), Nazar Damardeh (2011), Suliman Zakaria Suliman (2011), Prof Nikolaos (2011), Saranya Raksong (2012). Depreciation of domestic currency increases nominal exchange per US dollar which causes the shifting of money demand from M1 to M2 has observed by Tower (1975), Arango and Nadiri (1979, 1981), Arango and Nadiri (1981), Arize (1989), McNown and Wallace (1992), Bahmani-Oskooee 
and Rhree (1994), Lee and Chung (1995), BahmaniOskooee (1996), Muhammad Arshad Khan (2005), Parez et al (2010). However cost of holding money (interest rate on deposits) contains a negative relation with real demand for money as negative relation. Negative magnitude between demand for money and the cost of holding money has already been supported by Mohsen B, Charikleia E (2005), Qazi et al ,(2009), Singh, Parakash and Pandey, Manoj K. (2009), Noer Azam Achsani (2010), Nazar Damardeh (2011).

3) To test the stability of the money demand model for the conduct of optimal monetary policy. The rationale behind examining the stability, is that the previous studies on money demand specifically in Pakistan are roughly stable and do not hold any prompt position for growth oriented monetary policy. The proposed demand for money in Pakistan is purposely established so that the stability of the model than of earlier studies could be approached.

4) To see how this relationship support the effective alternations of monetary policy as well as fiscal policy in Pakistan. The improved monetary and fiscal driven changes will rebalance the unfavorable variations especially in exchange rate hence the improved policies can restore the confidence the people in Pak-rupee.

5) To make policy recommendations based on an estimation of a dynamic demand for money model in Pakistan that could hold a key position for an optimal monetary and fiscal policy analysis.

\section{REVIEW OF LITERATURE}

Economy of Pakistan portrays persistent inflation and increased nominal income. There is a perpetual growth in the money in circulation and the government finances its budget deficits heavily through printing new notes. Keeping in view the macroeconomic outlook of Pakistan and its affiliation with monetary aggregates in monetary policy endeavors to study money demand is fully justifiable.

Earlier studies on the subject were conducted mainly in industrialized countries like America and other developed countries. However the trend is now prompted in developing countries as well. This surge is principally prompted by the concern of Central banks and economic researchers who examined the impact of capital markets globalization, acceptance of flexible exchange rates, financial liberalization and internal market improvements on Real Demand for Money (Subramanian S. Sriram; 1999). In this regard Keynes (1936) pursued the three major purposes behind the people demand for money: 1) transactions 2) precautionary and 3) speculation. Money for transaction purposes is demanded by the business enterprises and individuals who buy and sell the goods and services. Speculation demand for money is related with a better knowledge of money market behavior ensures the people or firms to secure an optimal profits and another portion of cash held by the people to manage the sudden needs of money in business or home is known as precautionary demand for money. While as a friend of classical Milton Friedman (1956) argued that money demand in form of cash, bonds, equities and commodities is influenced by the changes in non human form of wealth, nominal expected rate of return on money, bonds and quantities with the nominal expected changes in their prices. Expected nominal return on bonds and quantities including their expected prices leave a negative influence on demand for money function whereas real income, non-human wealth and expected nominal rate of return on money found to positive coefficients in his model.

Furthermore real demand money gives an opportunity to test existence of Milton Friedman's dilemma i.e. as the nominal income increase at the onset of business cycle people do not increase money demand in short run. Researches by Goldfeld (1973) \& Chow (1966) also supports Friedman's hypothesis i.e. the short run income elasticity of money demand is found to be lower in their work: These low income elasticities (in short-run) are accordant with the Friedman's (1959) dilemma." (Akerlof; Short run money demand).

There are numerous of economic indicators cause the stimulation of real demand for money. In this regard several of studies from 1970 to 2010 have witnessed the relative importance of the variable nominal exchange rates as well as real exchange rate as determinant of money demand models in developing and developed economies. For examples: Tower (1975), Arango and Nadiri (1979, 1981), Arize (1989), Arize, A.C. (1989), Bahmani M, Malixi M (1991), McNown and Wallace (1992), Bahmani-Oskooee and Rhree (1994), Lee and Chung (1995), Kogar (1995), Choudhry, T. (1995), Bahmani-Oskooee (1996), Dr. Omar Marashdeh (1997), Bradley T. Ewing and James E. Payne (1999), Sonje (1999), Civcir (2000), Egoumé-Bossogo, P. (2000), Alkiswani M., (2001), N. Erjavec, and B. Cota (2003), Mutluer, D. and Yasemin, B. (2002), Akıncı, Ö. (2003), Harb, Nasri, (2003), Al-Zu'bi B., Khalid Saw'I, (2004), Muhammad Arshad Khan, Muhammad Zabir Shahid (Winter 2005), Aaron Mehrotra (2006), Akinlo, A. Enisan (2006), Sharifi-Renani, (2007), Samreth, Sovannroeun (2008), Muhammad Arshad Khan, Muhammad Samreth, Sovannroeun (2008), Abbas Valadkhani (2008), Samreth (2008), Dr. Pervez Azim (2010), Muhammad Aijaz Rasheed (2011), Nazar Dahmardeh and Hamid Raza Izadi (2011), Dr. AL-Abdulrazag Bashier (2011), Suliman Zakaria Suliman (2011), Prof. Nikolaos Dritsakis, (2011), Jihad Daghar, (2011), Jafar Haghighat (2011), Saranya Raksong (2012), Christopher S. Adam (2011). Similarly the rationale to take real income and interest rate as explanatory variables is obviously to ensure a significant impact on real demand for money Malixi M (1991), Anusic (1994), Ashfaque H. Khan (1994), Dr. Omar Marashdeh (1997), Treichel, V. (1997), Qayyum's (1998), Mohsen BahmaniOskooee (2002), Arshad khan (Winter 2005), Qayyum (2005), Tahir Mehmood (2005), Rehman (2005), Sharifi-Renani, (2007), Shigayuki HAMORI (2008), Samreth, Sovannroeun (2008), Qazi et al ,(2009), Singh, Parakash and Pandey, Manoj K. (2009), Noer Azam Achsani (2010), Parez et al (2010), Nazar Dahmardeh and Hamid Raza Izadi (2011), Suliman Zakaria Suliman (2011), Prof. Nikolaos Dritsakis, (2011), Nazar Dahmardeh and Hamid Raza Izadi (2011), Saranya Raksong (2012).

Keeping in view the above stated determinants of money demand, several of research papers to examine the influence of these factors in Pakistan have been published by Akhter (1974), Hossain, A. (1994), Mangla (1979), Khan (1980, 1982), Nisar and Aslam (1983), Ahmad and Khan (1990), Ali and Khan (1997), Qayyum, A. (1998), Qayyum, A. (2001), Qayyum, A. (2005), Muhammad Arshad Khan, Muhammad Zabir Shahid (Winter 2005), Zakir, (2006), Qazi et al ,(2009) and Dr. Pervez Azim (2010). However a few of them have adopted the provision of stability tests CUSUM and CUSUMSQ in their studies. But according to Qayyum (2005) "Generally, the M2 function is found to be stable. However with exception of Hossain (1994), Khan and Ali (1997), and 
Qayyum (1998, 2001), these studies ignored the time series properties of the relevant variables and therefore may be prone to spurious regression".

In our neighbor country India has also produced several empirical studies to estimate the money demand function and most of the estimations in India provided a stable function. For example: Takeshi INOUE and Shigayuki HAMORI (2008), Parakash Singh and Manoj K. Pandey (2009),

Arize, A.C. (1989) establishes an Asian money demand functions and argued that foreign interest rates, exchange rate depreciation and technological change are the most important determinants in Pakistan, Philippines, South Korea, and Thailand. While the suggestions by Bahmani M,

Malixi M (1991) put forward exchange rate depreciation in 13 developing countries caused demand for domestic currency decrease. On the other hand inflation and real income positively influenced the demand for monetary aggregate function.

Simmons (1992) examines the impact of opportunity cost variables like the domestic interest rate, expected exchange rate depreciation and inflation on the demand for money functions in five African economies. The error-correction modeling based empirical findings of Simmons (1992) concludes that different developing economies prevailing different diagnostic factors such as: the domestic interest rate is considered an important determinant of the money demand only in three out of the five countries, inflation plays an extremely important role in determining the demand for money in four out of five cases, the both domestic interest rate and expected exchange rate depreciation are significant for only one of the five African economies.

Dr. Omar Marashdeh (1997) using Johansen and Juselius Maximum likelihood method for a long-run cointegration and error correction methodology this paper develops long-run cointegrated relation in Malaysia establishing between the demand for money (M1) function and its determinants: income, price, interest rate and exchange rate from the period January 1980 to October 1994. The estimated demand function remains stable over the same period as is confirmed by Chow test. In the short run dynamic specification of the model, money demand (M1) depends on independent variables are: income, expected rate of inflation, 6-months mode of deposit rate, expected change of exchange rate, seasonal dummies, and the error correction from the long-run demand for money. Finally Dr. Omar Marashdeh (1997) also indicates existence of currency substitution prevails in Malaysia.

In case of in Tunisia an optimal monetary policy which is based on the stability of broad money functions (M2 and M4) as is examined by Treichel, V. (1997). The predictable outcomes of the monetary base multiplier are manipulated to achieve a certain cogrowth of the money supply which don't consider the role of inflation regime but in this case the short term interest rates must be targeted so as to the endogeneous base money supply could consistently grow with the growth rate of money supply.

Dekle, R. and Pradhan, M. (1997) concludes the case of rapid growth and ongoing changes in financial markets of Indonesia, Malaysia, Singapore and Thailand are the responsible of instable features in both narrowly defined and broadly defined monetary demand equations determined by the impact of liberalization of financial market.

In case of Norway Eitrheim, Æ. (1998) investigates the shocks in endogenously determined broad monetary balances are absorbed estimating a long run money demand relationship between money, prices and wages, while in shortrun these shocks were depicted during the period of financial deregulation.

Qayyum, A. (1998) contributes in Pakistan a stable long-run relation between money demand and its determinants: income, rate of inflation and bond rate. While in short-run dynamics rate of inflation and interest rate on deposits were concluded the most reliable variables in the model.

Using seasonally adjusted variables in Croatia, A. Babić (2000) contains the same findings that inflation coefficient is near to zero and at $95 \%$ confidence level this coefficient is insignificant.

A successful transformation of Guyana economy from a central control to a market economy emphasizes EgouméBossogo, P. (2000) studies a long-run cointegrating vector of real broad money demand (M2) function in Guyana from 1990:1 to 1999:9. Moreover a long-run model based on stable error correction mechanism (ECM) establishes the relationship between the real money demand and its determinants: real income, interest rate and exchange rate.

Christopher Adam (2000) presented his findings in Chile for a long-run cointegration between real money balances and its determinants using Johansen (1995) cointegration method from the period 1986 to 2000 . The existence of model is based upon the strong trend of stationarity has made robust singleequation possible. Error correction model (ECM) for its shortrun dynamics confirms the relative stability of model.

Error-correction model (ECM) for a short-run dynamics of the model sources Kannapiran C. A. (2001) to study the properties of money demand in Papua New Guinea (PNG). His findings suggest that an appropriate monetary policy for monetary targeting regime as proposed by the central bank in PNG. Although, the income elasticity of money demand is relatively lower than the most of developing countries. However a stable relationship between the demand for money in PNG and its determinants: Real GDP, nominal interest rate and inflation rate provide the strong support to the above stated policy implications.

Modeling framework in an open economy Nachega, J.C. (2001) investigates the behavior of M2 broad money demand in Cameroon contains own rate of return is positively sensitive and rate of inflation, currency substitution and foreign interest rate are negatively sensitive to the broad money. These estimations indicate the attachment unitary income elasticity with the quantity theory of money as well as the source of inflation as imported is revealed by above stated process of money demand relation.

Cuthbertson, K. and D. Bredin (2001) conclude the uncertain circumstances of Czech Republic raised at the end of 1992 are rarity caused of any currency substitution concerns. However despite the data limitation since the fragmentation of the Czech-Slovak Republics at earlier of 1993 Cuthbertson et al. (2001) found a long-run existence between real demand for money aggregates and its determinants: real income and inflation rate. 
Cluadia M. Buch, (2001) present empirical findings of narrow and broad forms of money demand in Jordan showed negative impact of the opportunity costs of holding money and positive impact of the volumes of transactions. This investigation over the period 1971-2005 is also extended for its long-run stability. Moreover Cluadia M. Buch, (2001) considers foreign interest rate, domestic interest rate or inflation as the proxy of cost of holding money.

Incorporating the methodology of Error Correction Model approach for short-run dynamics and the cointegration approach for a long-run existence for Syria Alkiswani M., (2001) estimates the demand for narrow money (M1) for the period 1974-1994 using the quarterly data. The estimations provided by him show a positive and significant impact of income and inflation rate which is taken as a proxy of cost of holding money and exchange rate leave a negative relation along with insignificant impact on money demand.

For the sack of better understanding of money multiplier behaviour in Pakistan Hafeez ur Rehman and Imtiaz Ahmed (2002) refer monetary base as an effective and important determinant of the monetary stock (M2) can resource an optimal monetary policy in Pakistan. An optimal monetary policy helps monetary authorities to control and regulate the total monetary assets (cash and others) in Pakistan keeping in view the targeted growth rate of GDP, a sustainable economic growth, the country's external account balance (surplus or deficit) and monetization of the economy.

N. Erjavec, and B. Cota (2003) review the Granger causality between real output to price level and concluded that growth of Croatian economic activity does not fully dependent on the independent stimulus of money demand analysis in short-run dynamics. It means that the expansion in the aggregate supply in the Croatian economy does not sufficiently absorb the excess aggregate demand which caused by the increase in income. On the other hand Vector Error Correction Model (VECM) indicates the interest rate and exchange rate in their short-run dynamics are considered exogenous variables econometrically.

The long run relationship for real demand for broad money with a unitary income elasticity, as was in Civcir (2000), Mutluer, D. and Yasemin, B. (2002) establish the same longrun as well as a stable broad money demand of deposits denominated in foreign currency with a quarterly data during the period 1987-2001. The findings Mutluer, D. and Yasemin, B. (2002) indicate the foremost factors influencing the broad money demand are the inflation rate and the CPI based real effective exchange rate established by CBRT.

For Euro area, Kontolemis, Z. G. (2002) reviews the stability of long run M3 money demand and refers the case to velocity shocks in Euro area caused the slow speed of adjustment from divergence to the equilibrium than the European Central Bank estimates.

Mohsen Bahmani-Oskooee (2002) with the help of ARDL cointegration framework examines a positive relation of real income, foreign interest rate and nominal effective exchange rate and negative relation of domestic interest rate with money demand function in Hong Kong as well as CUSUM and CUSUMSQ also confirmed the stability of model in long-run equilibrium.

Jae-Kwang Hwang (2002) using the Johansen and Jeselius maximum likelihood method of cointegration examines the long-run stability of the model through alternatively used both M1 and M2 monetary aggregates as the dependent variable in
Korea. On comparing the both narrow and broad forms of money holdings, M2 monetary aggregate found to be a longrun cointegrated relationship with real income and long-term interest rate along with the conclusion that long-term interest rate is a reliable proxy to measure the opportunity cost of holding money in Korea than short-term interest rate. However, M1 lacks holding any reliable cointegration with its all above determinants. Jae-Kwang Hwang (2002) suggests the control of broad money (M2) must be in consideration of monetary policy in Korea.

Akıncı, Ö. (2003) modeling the demand for real cash balances in Turkey with a quarterly data from 1987Q1 to 2003Q3 estimated the existence of long run relationship between real currency issued, interest rates on government securities, private consumption expenditure as scale variable and the exchange rate. However the magnitudes of income elasticity is found to be near unity, and there expected negative relationship of the opportunity cost holding money in the model.

Harb, Nasri, (2003) with the help of panel data for the period 1979-2000, use the FMOLS and Modified FMOLS models to estimate a long-run money demand function for the GCC's six countries through an alternatively used both M1 and M2 monetary aggregates as the dependent variable. While GDP, interest rate and expected exchange rate as independent variables. The selection of the interest rate and the expected exchange rate in the model is in response of measuring the opportunity cost of holding money. The estimated results of these both variables showed negative elasticities as required by the economic theory. While GDP as a scale independent variable in the model, showed a theoretical based positive elasticity of income. His model was also processed with the unit root test and the cointegration test showing all variables are integrated of order one and cointegrated.

Abbas Valadkhani and Mohammad Alauddin, (2003) estimate the demand for M2 function in eight developing countries with the major determinants: inflation rate, long-run and short-run interest rates, real income and the US long-term interest rate influencing. He used annual time series data for the period 1979-1999. The estimated results on the basis of seemingly unrelated regression (SUR) estimation technique showed a positive impact of income, whereas negative impact of the all types of interest rate and the inflation rate on money demand.

Al-Zu'bi B., Khalid Saw'I, (2004) using the OLS estimation method, examines the stability of the money demand function for both broad and narrow in Jordan. Their empirical findings based on the sample of the data from 1971-2000, showed the independent variables income elasticity was positive as per the sense of economic base whereas the results opposed the theoretical perception of economics contain the price elasticity and exchange rate elasticity were also positive.

Altınkemer, M. (2004) estimates a stable long run base money demand function and a stable long run M2Y function for Turkey. The joint endogeneity of inflation and real base money of Altınkemer, M. (2004) empirical findings indirectly support the inflation targeting except monetary targeting in Turkey. However a mature condition for inflation targeting framework cannot be so much optimal without a persistent growth and development of base money.

In Pakistan (1982Q2-2004Q4) both long run and short run impact of real income, inflation rate, foreign interest rate and real effective exchange rate indicated a significant relation 
with real money balances where as the short-run dynamics of real money balances showed a smaller effect of these determinants and the error correction model adjusts to restore $11.88 \%$ of a disequilibrium from the previous year to the current year Muhammad Arshad Khan, Muhammad Zabir Shahid (Winter 2005).

Qayyum, A. (2005) cites his study of M2 money demand using time series data from 1960-1999, in Pakistan reveals rate of interest, return on bond and market rate to be the vital determinants of money demand in the long run.

Cem SAATÇIOGLU (2005) finds the instable Turkish broad money (M2Y) demand function within estimation period from 1987Q1-2004Q2 and concluded domestic economic crises conditions, political uncertainties and inflationary expectations in Turkey were attributed to a highly instable growth performance of the Turkish economy as well as the rapid financial innovation process decreases the correlation between monetary aggregates and income indicate in Turkey which makes the broad money demand is very insensitive to real income.

Tahir Mehmood (2005) considers the concept of money demand using Johansen Juselius (1990) test for cointegration for long-run and Error Correction Model for short-run, estimated the relationship between the money, interest rate, output and the prices in Pakistan and found one cointegrating vector among these variables.

Mohsen B, Charikleia E (2005) using cointegration analysis approach and the cumulative sum and cumulative sum of squares tests in Greece during the period 1975Q1 to 2002Q4, examined the long-run relation included interest rates and the real income as the determinant factors of demand for money balances M1 and M2 and the stability of the model respectively. The estimation results showed that both $\mathrm{M} 1$ as well as M2 contain a positive elasticity with income and negative elasticity with interest rate. However, the stability tests confirmed M2 could not be a stable function only M1 is a stable function.

Halicioglu, Ferda and Ugur, Mehmet (2005) analyze the cointegration procedure and stability of the narrow money (M1) demand function using annual data from the period 1950-2002 in Turkey. They demonstrated a stable and cointegrated demand for money function which could be used as an intermediate target of monetary policy in Turkey. However the cointegration procedure of money demand function along with the CUSUM and CUSUMSQ tests for the stability of the model were initially proposed by Pesaran et al. (2001) and Brown et al. (1975) respectively.

Using an econometric technique autoregressive distributive lag (ARDL) approach on Pakistan economy during the period 1982Q2-2002Q4 Muhammad Arshad Khan, Muhammad Zabir Shahid (Winter 2005) concludes the long-run real income, inflation rate, foreign interest rate and real effective exchange rate have a significant impact on real money balances in Pakistan. While short-run dynamics of real money demand show that the effects of all the determinants except real income are much smaller than long run. Despite the government has been pursuing the economic reforms since the late 1980s the overall results reveal that the demand for real money balances in Pakistan is stable,

Canova, Luciano (2006) concludes the existence of a long run the relationship between money balances and income in Jamaica. While in the short run the ineffectiveness of monetary policy in Jamaica is attributed to the less significant and instable correlation between money balances and income. Canova, Luciano (2006) argues the two different financial crises should have an impact in affecting significant and stability of the model in short-run. Role of IMF in lessening its kind on Jamaican government may be another important element behind.

Aaron Mehrotra (2006) examines the demand for broad money M2 in the Chinese economy and found a stable money demand relationship in a vector error correction framework, together with increased inflation led by the shocks of broad money observation. Aaron Mehrotra (2006) suggests a successful conduct of the PBoC's current policy that specifying intermediate targets defined in terms of the growth rate of broad money M2 is attributed to the movements of nominal effective exchange rate if taken into modeling the demand for broad money M2. He prefers the interest rates move to a PBoC's current policy that specifies an inflation target for the monetary authority should be regarded a more prominent determinant of the demand for broad money M2.

Akinlo, A. Enisan (2006) with the help ARDL framework established a long-run relation of money (M2) demand function in Nigeria during the period 1970:1-2002:4. ARDL cointegration method showed the relative effectiveness of income, interest rate and exchange rate in the model where as the CUSUM and CUSUMSQ tests, to examine the stability of M2 money demand for Nigeria revealed the econometric model is comparatively stable in CUSUM test.

Aziz KUTLAR (2007) applying VAR model approach for long-run cointegration analysis, Granger causality for the short-run dynamics and misspecification $\mathrm{ARCH}$ and $\mathrm{AR}$ tests established a causal relation between real money demand, income, money and treasury bond interest return, and inflation.

Sharifi-Renani, (2007) employs auto regressive distributive lag (ARDL) cointegration framework and examined income elasticity and exchange rate are positively while inflation elasticity negatively influenced the M1 monetary aggregate. The stability level of the selected M1 money demand function applying CUSUM and CUSUMSQ tests was found between 1985 and 2006

Hsing, Y (2007) finds the log linear transformation estimation of money demand function which is positively related with GDP and currency appreciation, and negatively related by domestic interest rate and foreign interest rate, is better estimation than linear and Box-Cox transformation.

Samreth, Sovannroeun (2008) computing demand for money function in Cambodia made an inference of CUSUM and CUSUMSQ that shows comparatively instable long-run model applying an autoregressive distributive lag (ARDL) approach to cointegration. Anyhow the short-run dynamics of the model through error correction model (ECM) reveals real income positively, inflation negatively and exchange rate is negatively related elasticity coefficients as expected before.

Inoue T, Shigeyuki H (2008) for the demand of monetary aggregates concluded that no long-run relationship is found for M3 except the co-integrating vector among real money balance like M1 and M2, interest rates, and output is represented. 
Long, Dara and Sovannroeun Samreth (2008) using autoregressive distributive lag (ARDL) approach for long-run cointegration and error correction model (ECM) approach for short-run dynamics establish monetary models of exchange rate and end up their studies concluding the robust as well as the stable relationships between the variables.

Qazi et al, (2009) estimates money demand from 1971-2006 and finds a significant impact of stock prices over money demand in Pakistan.

Han Y, Pei-Tha G (2009) presenting ECM concluded a longrun relationship between real money balances and its determinants.

Rao, B. B. and Gazi Hassan, (2009) winded up very stable estimation for money (M1) demand function of 11 Asian countries from 1970 to 2007 with no structural break.

Baharumshah, Ahmad Zubaidi, Siti Hamizah Mohd and A. Mansur M. Masih (2009) modeled the demand for money (M2) function from 1990Q4 -2007Q2 in China via the autoregressive distributed lag (ARDL) approach and conclude a stable cointegration among M2 and its determinants real income, inflation, foreign interest rates and stock prices.

To analyze the money demand behavior of Croatia economy B. Skrabic, and N. Tomic-Plazibat (2009) use Johansen cointegration framework approach to examine the money demand function and the evidence from the empirical findings provide that real industrial production and exchange rate are the most important variables of money demand in the longrun, while in short-run only interest rate is significant indicating slow speed of adjustment from disequilibrium to the equilirium.

Samreth (2008) emphasizes the designing effective monetary policy in Cambodia depends on effective structure of money demand function. For this purpose Samreth (2008) established the money demand function which is estimated within cointegration approach framework founded by Pesaran, M. H., Y. Shin and R. J. Smith (1996, 2001). Cointegration approach framework indicated the existence of long-run relationship of the variables reveal the elasticity coefficient of real income is positively expected, inflation's elasticity coefficient is negative as expected and the currency substitution symptom in Cambodia is very well supported by exchange rate contains a negative elasticity coefficient as well as it fails to produce any significant relation with money demand function as incorporated by t-test. Moreover, CUSUM and CUSUMSQ tests are also conducted to ensure the estimated model is roughly stable.

Dr. Pervez Azim (2010) found income and inflation have positive while exchange rate has negative impact over Real Demand for Money in the long-run using auto regressive distributive lag (ARDL) approach to cointegration. CUSUM test resulted for both M1 and M2 are instable models showing the CUSUM statistics lies outside the critical range while CUSUMSQ concluded some safe and trust worthy consequence for M2 as well as M1 money demand model is considered stable during 1973 to 2007.

S. P. Jayasooria (2010) explores long term dynamic behavior of the narrow money supply to investigate the nexus between money demand and minimum wages and their impact on macroeconomic stability in Sri Lanka. The empirical approach was directed to estimate the coefficients of the Vector Error
Correction Model (VECM) to determine the long term elasticity of the dynamic model, and to examine the stability of the macroeconomic equilibrium.

Noer Azam Achsani (2010) presenting stable long-run money (M2) demand function through autoregressive distributive lag (ARDL) method of cointegration concluded the magnitude of real income and interest rate in Indonesia during 1990:1 to 2008:3 were positive and negative respectively. Anyhow vector error correction model (VECM) capturing a short-run dynamics, approves negative but insignificant relation of interest rate with money (M2) demand function.

Haroon Sarwar, Zakir Hussain and Masood Sarwar (2010) scrutinize the more realistic, information content and stable money demand function based on broader Divisia aggregate $\left(\operatorname{Div} M_{2}\right)$ in Pakistan and suggested State Bank of Pakistan Divisia type-weighted aggregates is comparatively better than of Simple sum aggregate technique.

Another considerable research conducted in Pakistan to investigate causal relation money and other real economic variables using Johansen cointegration technique for long run cointegration and Granger causal tests for the short run dynamics Muhammad Aijaz Rasheed (2011).

The demand for money function estimated in Iran for the period 1971 to 2005 with the help of auto distributive lag (ARDL) cointegration procedure for a long-run analysis which concluded the t-values of the determinants income, exchange rate, inflation rate and interest rate lied into the critical region while error correction model (ECM) capturing short-run dynamics resulted about 50\% speed of adjustment Nazar Dahmardeh and Hamid Raza Izadi (2011).

Dr. AL-Abdulrazag Bashier (2011) examines the money demand function for the period 1975-2009 in Jordan. Dr. ALAbdulrazag Bashier (2011) incorporated different statistical techniques to approach a reliable studies could contribute in an effective monetary policy in Jordan. These statistical techniques along with conclusion included for the following procedures: the Augmented Dickey-Fuller (ADF) unit root tests proposed by Dickey- Fuller (1981) reveal that all time series data are integrated of order one I(1), Johansen-Juselius (1990) Cointegration analysis that shows the determinants of the model are cointegrated along with a positive relationship between money demand and the level of income while the relationship is negative for interest rate and exchange rate depreciation and CUSUM and CUSUMSQ fot stability tests reveal that M2 money demand in Jordan is stable.

Jihad Daghar (2011) applying Bounds testing procedure upon a time series data from 1990Q1 to 2009Q4 estimated long-run stable money demand function in Ghana. In short-run dynamics the error correction mechanism (ecm) contains $47 \%$ speed of adjustment of a disequilibrium of the model from the previous quarter into the current quarter.

Arqam AL-Rabbaie (2011) models the effect of financial innovation of its stochastic form on US narrow and broad money demand functions in order to obtain plausible estimates for the economic variables in US and concluded the importance of financial innovation in narrow and broad money demand functions restored the effectiveness of monetary policy to improve the forecasting ability that based on parameters estimates. 
Suliman Zakaria Suliman (2011) concludes the existence and stability of long-run relation between real money balance and its determinants such as real income, real exchange rate and inflation in Sudan applying Johansen Maximum Likelihood procedure from the period 1960 to 2010 . Error correction model showing $43 \%$ speed of adjustment into its convergence from disequilibrium estimated comparatively weak coefficients for its short-run dynamics.

Prof. Nikolaos Dritsakis, (2011) in Hungary estimates a longrun relationship between the demand for money and its determinants real income, inflation rate and nominal exchange rate, using autoregressive distributive lag (ARDL) cointegration analysis. The stability of the model was based on bounds testing approach.

Nazar Dahmardeh and Hamid Raza Izadi (2011) estimate demand for money in Iran for period 1971-2005 and on the basis of the autoregressive distributed lag (ARDL) method Nazar Dahmardeh and Hamid Raza Izadi (2011) concluded a failure of cointegration. On the other hand the Error Correction Model (ECM) reveals $50 \%$, speed of adjustment deviation of equilibrium.

Yamden Pandok Bitrus (2011) employing a multiple regression on both narrow as well as broad money established a relation between demand for money and its determinants income, interest rate, exchange rate and the stock market. CUSUM test and the unit root-test for stationarity of the variables concluded a stable demand for money function in Nigeria as well as income is most significant determinant of the model.

Christopher S. Adam (2011) develops an econometric model of the demand for M2 in Tanzania, using quarterly data from 1998 to the present and concluded the portfolio behavior of the demand for M2 responds to expected inflation and to exchange rate depreciation, with weaker effects from interest rates caused the continuous decline in velocity since the late 1990s is associated with a transformation of economic activity that has cumulatively increased the monetary intensity of GDP. The study concludes the policy implications of our results, including their relevance to the velocity-forecasting exercise that plays a vital role in the Central Bank of Tanzania's policy framework.

Inflation targeting framework in Thailand requires a stable money demand function. In this regard Saranya Raksong (2012) estimates a relationship between a real demand for M1 and M2 and its determinant real income, exchange rate and external interest rate for the period 2001Q1 to 2010Q1. The empirical results showed an existence of the model in longrun equilibrium using co cointegration analysis.

\section{DATA SOURCE AND METHODOLOGY DATA SOURCE AND VARIABLES}

This paper uses annual time series data from 1973 to 2010 analyzing the long-run cointegration among the variables outlined below consisting of Real Demand for Money $\left(M d_{t}\right)$ as a ratio of M2 to GDP Deflator, Call Money Rate $\left(C M R_{t}\right)$, Real Income $\left(R y_{t}\right)$ as a ratio between GDP to GDP deflator and Exchange Rate in terms of local currency unit (LCU) per US dollar $\left(E R_{t}\right)$.

Many of the researchers have already taken these variables in several studies of money demand. For example: Dr. Omar Marashdeh (1997), Subramanain S. Sriram (1999),
Christopher Adam (2000), Abdul Qayyum (2001), Abbas Valadkhani (2002), Mohsen Bahmani-Oskooee (2002), Tahir Mehmood (2005), Abdul Qayyum (2005), Reza (2005), Arshad khan (2005), Shamim Ahmad (2005), Sharifi-Renani (2007), Samreth, Sovannroeun (2008), Mohsen (2007), Noer Azam Achsani (2010), Dr. Pervez Azim (2010), Christopher S. Adam (2011), Prof. Nikolaos Dritsakis (2011), Nazar Damardeh (2011), Suliman Zakaria Suliman (2011) and Saranya Saranya Raksong (2012).This sample period is constrained by the availability of data which is sourced from the various series of Central Bank of Pakistan (SBP), Economic Survey of Pakistan (2010-11), World Development Indicator (WDI) and International Financial Statistics (IFS) a publication of International Monitoring Fund (IMF). All the variables have been utilized are logarithm form except call money rate.

To examine long-run equilibrium as well as the short-run dynamics of the proposed money demand model we firstly will assure the stationarity properties of the variables selected for estimated in this study. The selected variables if are stationary at level $\mathrm{I}(0)$ the researchers used Ordinary Least Square (OLS) method of regression. If the variables are stationary at first difference $\mathrm{I}(1)$ or at second difference $\mathrm{I}(2)$ then most of the research practitioners relied upon Johansen and Juselius maximum likelihood cointegration method for long-run and Error Correction Model for the short-run dynamics. In case of non existence of long-run cointegration among the variables employing Johansen cointegration technique then to examine the short-run dynamics among the variables Granger causal tests mostly is used.

On some doubtful grounds the reliability of Johansen and Juselius cointegration method was pointed out. Such as if some of variables of the proposed model are stationary at level $\mathrm{I}(0)$ and others are at first difference $\mathrm{I}(1)$. So the situation which represents all the variables are not showing the same order of stationarity we have to rely on a cointegration technique named Autoregressive Distributive Lag (ARDL) developed by Pesaran and Shin (1995) and Pesaran, Shin and Smith (1996). ARDL approach contains both long-run cointegration among the variables as well as it also examines the short-run dynamics named Error Correction Method. ARDL procedure of cointegration for a long-run equilibrium and short-run dynamics of the model has already been utilized by several research economists. Such as: Siddiki (2000), Mohsen Bahmani-Oskooee (2002), Muhaamd Arshad Khan (2005), Sharifi-Renani (2007), Samreth, Sovannroeun (2008), Mahedhiran Nair (2008), Salvator CAPASO (2008), Rao, B. B. and Gazi Hassan, (2009), Noer Azam Achsani (2010), Dr. Pervez Azim, (2010), Prof. Nikolaos Dritsakis (2011), Nazar Dahmardeh (2011), Jihad Daghar (2011) and Hamid Raza Izadi (2011). All calculations are carried out using Microfit 4.1.

\section{SPECIFICATION OF THE FUNCTION OF REAL DEMAND FOR MONEY}

This study implement the following specification of real demand for money function can be written as:

$$
M_{t} / P_{t}=f\left(Y_{t} / P_{t}, R_{t}, E_{t}, u_{t}\right)
$$

Where:

$M t=$ Money Stock (M2) which includes all Pak-rupee denominated currency in circulation plus demand, time and foreign currency deposits. $P t=$ Price Level (GDP deflator) 
$Y t=$ Nominal Income (GDP)

$R t=$ Interest Rate including Call Money Rate (CMR)

$E t=$ Exchange Rate (Nominal)

\section{ECONOMETRIC MODEL}

Using the logarithmic form for the above discussed variables and redefining the specification into the following multiple semi log linear regression model.

Laidler (1973) presents a critical point faced by the researchers that is the non-observability problem of money demand function. Considering the equilibrium in the money market the monetary authorities have to make an important assumption that is the quantity of money supplied and demanded are equal to each other hence only the measurement of the quantity of money supplied let the monetary authorities to approach the estimated quantity of money demand in a country.

Theory of demand for money function contains an extensive literature has been presenting since the times classical school of thought. The functional relationship between the quantity of money demanded and its determining factors that present the definition of the money stock monetary variable (M1, M2 and M3) and the appropriate specification of scale that is income or wealth variable, opportunity cost variables and besides some other variables that might systematically affect the demand for money function. The prior expectation from the theoretical literature a money demand function should contain a scale such as wealth variable or income variable to identify the economic activity relating to the level of transactions in the economy and another variable representing the opportunity cost of holding money Suliman Zakaria Suliman (2011).

\section{MONETARY VARIABLE}

The M2 definition of money is taken by the most of researchers and monetary authorities to examine the money demand function in Pakistan. The most justified rationale behind M2 definition of money is that the response of domestic currency depreciation (M1) leads to increase the domestic currency value of foreign assets in terms of M2. So M2 as an investment-oriented definition of money attracts the holders to convert their foreign assets again into domestic currency. M2 is a broader concept of money supply in Pakistan than M1 Muhammad Arshad Khan, Muhammad Zabir Shahid (Winter 2005).

\section{SCALE VARIABLE}

The demand of money is related to satisfy the volume of the transactions where the amount of transactions is directly proportional to the level of real income. So the first and the most important determinant of the money demand function is the scale variable which is considered tool also to measure the level of economic activity. Scale variable positively influences the demand for money as its definition includes real income variable. The real income variable as the ratio of Gross National Product (GNP) or Gross Domestic Product (GDP) to Gross Domestic Product (GDP) deflator is taken into the consideration. Such significant relation between real demand for money and real income is supported by several of researchers in the Pakistan and other developing countries Ashfaque H. Khan (1994), Mohsen Bahmani-Oskooee (2002), Arshad khan (Winter 2005), Rehman (2005), Mohsen B, Charikleia E (2005), Renani (2007), Samreth, Sovannroeun (2008), Parez et al (2010), Noer Azam Achsani (2010), Nazar
Damardeh (2011), Suliman Zakaria Suliman (2011), Prof Nikolaos (2011), Saranya Saranya Raksong (2012).

\section{OPPORTUNITY COST VARIABLE}

Demand for money function is affected by an opportunity cost variable which is intended to measure the yield on money against other assets held than of cash. This variable is usually used as an interest rate. So due to non availability of the variable interest in Pakistan, we have used call money rate as proxy of interest of interest rate which is inversely elastic with real demand for money in Pakistan. The negative magnitude of call money rate with real demand for money is supported by Mohsen Bahmani-Oskooee (2002), Mohsen B, Charikleia E (2005), Qazi et al ,(2009), Singh, Parakash and Pandey, Manoj K. (2009), Noer Azam Achsani (2010), Nazar Damardeh (2011).

\section{OTHER VARIABLES}

In most of developing countries like Pakistan exchange rate variable as a determinant of money demand is used to comprehend the phenomenon of currency substitution from M1 to M2 in many studies on the demand for money function. Mundell AR (1963) for the first time suggests the inclusion of the variable exchange rate in the standard function of money demand. The exchange rate, here, is defined as the amount of domestic currency per US dollar. Therefore, the increase or decrease of foreign exchange rate is attributed to the depreciation or appreciation of domestic currency against foreign currency.

\section{EQUATION NO: (1.1)}

$$
\begin{aligned}
\ln R M d_{t}=\beta_{0}+ & \beta_{1} \ln \left(\mathrm{Ry}_{\mathrm{t}}\right)+\beta_{2} \ln \left(\mathrm{ER}_{\mathrm{t}}\right)+\beta_{3}\left(\mathrm{CMR}_{\mathrm{t}}\right) \\
& +U_{t}
\end{aligned}
$$

Where real demand for money (RMd) a ratio of M2 to GDP deflator, is a dependent variable where as M2 includes M1 plus Time Deposits (whereas, real income (Ry), foreign exchange rate which is presented in local currency per US dollar (ER) and call money rates (CMR) are the independent variables. On the basis of preliminary analysis all the variables have been presented in (ln) natural logarithmic form except call money rates (CMR). Log linear function is more suitable than of linear function as it is argued on theoretical as well as empirical bases Ehrlich (1977) and Layson (1983). Natural log transformation of the data reduces its variability of variance. To summarize the prior expectations for the coefficients are as follows: $\beta_{1}>0, \beta_{2}>0$ or $\beta_{2}<0$ and $\beta_{3}<0$.

According to the theoretical literature as well as the previous studies the sign of parameter $\beta_{1}$ mostly considered positive as a relation between real income and real demand for money. It means if real income increases this will leave a positive influence in real demand for money of an economy and vice versa Mohsen Bahmani-Oskooee (2002), Arshad khan (Winter 2005), Rehman (2005), Mohsen B, Charikleia E (2005), Renani (2007), Samreth, Sovannroeun (2008), Noer Azam Achsani (2010), Parez et al (2010), Nazar Damardeh (2011), Suliman Zakaria Suliman (2011), Prof Nikolaos (2011), Saranya Raksong (2012).

As the economy of Pakistan which was severely heart from the shocking changes in nominal exchange rate per US dollar. If more domestic money is required to buy let say one US dollar or the depreciation of domestic currency will push the value of foreign assets upward, held by the people or residents hence rising exchange rate in local currency to buy one dollar will definitely raise the value of broad money (M2). The 
positive sign of coefficient $\beta_{2}$ shows the depreciation of domestic currency increases nominal exchange per US dollar which causes the shifting of money demand from M1 to M2. The same argument was supported by Tower (1975), Arango and Nadiri (1979, 1981), Arango and Nadiri (1981), Arize (1989), McNown and Wallace (1992), Bahmani-Oskooee and Rhree (1994), Lee and Chung (1995), Bahmani-Oskooee (1996), Muhammad Arshad Khan (2005), Parez et al (2010).

"It is found that income and the interest rate are not sufficient for the formulation of a long-run stable demand for M1 and M2 money in Chile. In order to identify a long-run stable money demand function for M1 and M2, the nominal effective exchange rate should be incorporated" Bradly T. Ewing (1999). The rationale of incorporating exchange rate into the model of money demand is supported by several researchers. For example: Tower (1975), Arango and Nadiri (1979, 1981), Arize (1989), McNown and Wallace (1992), Bahmani-Oskooee and Rhree (1994), Bahmani-Oskooee (1996), Dr. Omar Marashdeh (1997) and Bahmani-Oskooee and Techaratanachai (2001), Muhammad Arshad Khan (2005).

In case of coefficient $\beta_{3}$ contains a negative relation with real demand for money as negative relation is supported by Mohsen B, Charikleia E (2005), Qazi et al ,(2009), Singh, Parakash and Pandey, Manoj K. (2009), Noer Azam Achsani (2010), Nazar Damardeh (2011).

This model was also investigated for any specification error if occurs. For this purpose Ramsey RESET test was incorporated which states if computed F-value is significant then the selected model is considered specifically wrong $\mathrm{J}$. B. Ramsey (1969). In this model the calculated F-statistic lies outside the range of critical values at 5 percent level of significance and therefore, no specification error in our model has been found.

In this research paper we have examined the model applying auto regressive distributive lag (ARDL) approach to cointegration in the long-run. The beauty ARDL model that it deals with a single cointegration equation as well as all the variables to be integrated in model are $\mathrm{I}(0)$ or $\mathrm{I}(1)$ or even both $\mathrm{I}(0)$ and $\mathrm{I}(1)$ integrated (Pesaran and Shin 1999) can be processed for cointegration through ARDL approach. Pesaran and Shin (1999) argued that ARDL approach to cointegration provides robust results and super consistent estimates of the long-run coefficients in case of small samples. The Engle and Granger (1987) test, maximum likelihood based Johansen (1988, 1991) and Johansen Juselius (1990) tests are the most widely used methods to investigate the cointegration (long run equilibrium relationship) among the variables Muhammad Ilyas (2010). These methods require that all the variables included in the model must be stationary at first difference, i.e. I(1). So these techniques limit the stationarity of the data as well as the model containing the small samples are estimated with implausible results Muhammad Ilyas (2010). Autoregressive distributive lag (ARDL) approach to cointegration avoids the said limitations. Pesaran, Shin and Smith (1996) and Pesaran and Shin (1999) developed this approach whereas Pesaran et al.(2001) developed it further.

Due to various econometric advantages over other methods of cointegration this approach has gained wide acceptance. This approach, contrary to other approaches, does not necessitate all the variables to be integrated of the same order, i.e. I(1).

Considering above advantages of ARDL approaches to cointegration, we specify the following model:

\section{EQUATION NO: (1.2)}

$$
\begin{aligned}
\Delta \ln \left(R M d_{\mathrm{t}}\right)=\beta_{0} & \sum_{\mathrm{i}=1}^{\mathrm{q}} \beta_{1 i} \Delta \ln \left(R M d_{\mathrm{t}-1}\right) \\
& +\sum_{\mathrm{i}=0}^{\mathrm{q}} \beta_{2 i} \Delta \ln \left(R y_{\mathrm{t}-\mathrm{i}}\right)+\sum_{\mathrm{i}=0}^{\mathrm{q}} \beta_{3 i} \Delta\left(E R_{\mathrm{t}-\mathrm{i}}\right) \\
& +\sum_{\mathrm{i}=0}^{\mathrm{q}} \beta_{4 i} \Delta \ln \left(C M R_{\mathrm{t}-\mathrm{i}}\right) \\
& +\beta_{5} \ln \left(R M d_{\mathrm{t}-1}\right)+\beta_{6} \ln \left(R y_{\mathrm{t}-1}\right) \\
& +\beta_{7} \ln \left(E R_{\mathrm{t}-1}\right)+\beta_{8}\left(C M R_{\mathrm{t}-1}\right)+v_{t}
\end{aligned}
$$

Where $\Delta$ is the first difference operator, $q$ is optimal lag length, $\beta 1, \beta 2, \beta 3$, and $\beta 4$ represent the short run dynamics of the model and $\beta 5, \beta 6, \beta 7$, and $\beta 8$ are the long run elasticities. The long-run elasticity between the real demand for money (M2) and its determinants real income, exchange rate (LCU per US dollar) and call money rate (proxied by interest rate on deposits) can be examined through the formal procedure of computing the F-statistics. The F-statistics includes the null hypothesis $\mathrm{H} 0$ : $\beta 5=\beta 6=\beta 7=\beta 8=0$ for no cointegration or no long-run relationship between the variables while the alternative $\mathrm{H} 1: \beta 5 \neq 0, \beta 6 \neq 0, \beta 7 \neq 0, \beta 8 \neq 0$ hypothesis present if there exists a long-run cointegration or long-run relation between the variables. Before running the ARDL model we tested the level of integration of all variables because if any variable is I(2) or above ARDL approach is not applicable. For this we use Augmented Dickey-Fuller test (ADF) and Philips-Perron test (PP). In order to find the long run relationship as given in equation (1.2), we conducted bound test approach using $\mathrm{F}$ - test with two bounds, i.e. lower bound and upper bound. The null hypothesis assumes no cointegration among variables. If the value of F-statistic is greater than upper bound then the null hypothesis is rejected and if it is less than lower and upper bounds then the null hypothesis is accepted and if it falls between the lower bounds the test is inconclusive. After testing for long-run cointegration the selection of lag orders of variables is very important because the appropriate lag selection enables us to identify the true dynamics of the models. To check the performance as well as the true dynamics of the estimated model we use Akaike Information Criteria (AIC) or Schwarz Bayesian Criteria (SBC) for an optimal lag length of variables. This paper also goes through the stability tests, namely, Cumulative Sum (CUSUM) and CUSUM of Squares (CUSUMSQ) of recursive residuals, originally proposed by Brown et al. (1975) are also conducted. An error correction version of equation (1.3) is given as below:

\section{EQUATION NO: (1.3)}

$$
\begin{aligned}
\Delta \ln \left(R M d_{t}\right)=\beta_{0} & \sum_{i=0}^{q_{1}} \beta_{1 i} \Delta \ln \left(R M d_{t-i}\right) \\
& +\sum_{i=0}^{q 2} \beta_{2 i} \Delta \ln \left(R y_{t-i}\right)+ \\
& +\sum_{i=0}^{q_{3}} \beta_{3 i} \Delta \ln \left(E R_{t-i}\right) \\
& +\sum_{i=0}^{q_{4}} \beta_{4 i} \Delta\left(C M R_{t-i}\right)+\lambda E C_{t-1}+\varepsilon_{t}
\end{aligned}
$$

Where $q 1, q 2, q 3$, and $q 4$ represent optimal lag length, $\lambda$ is the speed of adjustment parameter and EC represents the error 
correction term derived from long run relationship as given in equation (1.3).

\section{EMPIRICAL FINDINGS}

Modeling the real money demand function applying autoregressive distributive lag (ARDL) approach to cointegration and the testing of the order of integration of the individual series selected in this study. The test of order of integration has been developed several procedures the most popular of them are: Augmented Dickey-Fuller (ADF) test due to Dickey and Fuller (1979, 1981), and the Phillip-Perron (PP) due to Phillips (1987) and Phillips and Perron (1988) unit roots test procedure at level and at first difference reported in Table 2.1 showing the analysis of the time series based on $\mathrm{ADF}$ and PP unit root tests indicate that the computed values of the time series of variables: real money demand, real income, exchange rate (LCU per US dollar) and call money rate (proxy of interest rate on deposits) at their level are less than the critical value $(-3.626784)$ at the $1 \%$ level of significance the null hypothesis presents the presence of a unit root cannot be rejected. However the null hypothesis is rejected for the first differences since their computed values exceed the critical values at the $1 \%$ level of significance keeping in view the stationarity is achieved at first difference at one percent level of significance indicated by $(* * *)$.

Given the unit-root properties of the variables, we proceed to estimate whether there is a long-run cointegration relationship among the variables in equation (1.2) by using Autoregressive distributive lag (ARDL) approach to cointegration. This approach lies in the fact that it can be applied irrespective of whether the variables are $\mathrm{I}(0)$ or $\mathrm{I}(1)$ or $\mathrm{I}(0)$ and $\mathrm{I}(1)$ both in Model (Pesaran and Pesaran 1997). The results of ARDL approach to cointegration have been taken using Microfit (5.0).

TABLE 2.1

Unit Root Test Results

\begin{tabular}{|c|c|c|c|c|}
\hline Variables & $\begin{array}{c}\text { Aug. } \\
\text { Dickey } \\
\text { Fuller } \\
\text { Test } \\
\text { Statistic } \\
\text { At 1(0) }\end{array}$ & $\begin{array}{c}\text { Aug } \\
\text { Dickey } \\
\text { Fuller } \\
\text { Test } \\
\text { Statistic } \\
\text { At 1(1) }\end{array}$ & $\begin{array}{c}\text { Philips- } \\
\text { Perron } \\
\text { Test } \\
\text { Statistic } \\
\text { At } 1(0)\end{array}$ & $\begin{array}{c}\text { Philips } \\
\text { Perron } \\
\text { Test } \\
\text { Statistic } \\
\text { At 1(1) }\end{array}$ \\
\hline $\ln R M d_{t}$ & -0.58 & $-5.66 * * *$ & -0.58 & $-5.77 * * *$ \\
\hline $\ln R y_{t}$ & -0.28 & $-3.92 * * *$ & -0.76 & $-3.91 * * *$ \\
\hline $\ln E R_{t}$ & 0.86 & $-4.20 * * *$ & 0.54 & $-4.18 * * *$ \\
\hline$C M R_{t}$ & $-4.30 * * *$ & $-5.20 * * *$ & $-2.69 *$ & $-5.17 * * *$ \\
\hline
\end{tabular}

McKinnon (1996) Critical Values: $1 \%(-3.626784) ; 5 \%(-2.945842) ; 10 \%(-2.611531)$ for ADF and PP at I (1)
McKinnon (1996) Critical Values: $1 \%(-3.621023) ; 5 \%(-2.943427) ; 10 \%(-2.610263)$ for ADF and PP at I(0)

Results of the long-run relationship are sensitive to lag-length selected in the model (Bahmani-Oskooee and Bohal, 2000). Table 2.2 presents the computed F-statistic to select optimal lag-length in the model. According to Pesaran et al. (2001), with lag if order 1 the lower and upper bound values at 95 percent significance level are 3.79 and 4.85 respectively.
Table 2.2 shows that the computed value of F-statistic (4.90) is greater than the upper bound value of F-statistic which helps us to reject the null hypothesis of no long- run relationship. Therefore, we conclude that there is long-run relationship among the variables.

TABLE 2.2

\section{F. Statistic for Testing the Existence Of Long-Run Relationship}

\begin{tabular}{|c|c|}
\hline Order of Lag & F-Statistic \\
\hline 2 & 5.6644 \\
\hline
\end{tabular}

The lower and upper bound values (3.566 and 4.8395 at 95 percent) for F-statistic are taken from Microfit 5.0 developed by Bahram Pesaran and M. Hashem Pesaran.

To select the optimal lag orders of the variables we have used Schewarz Baysian Criterion (SBC) and concluded the F-static value 5.6644 stays above the upper bounds of the critical values 4.8395 therefore null hypothesis of no long-run cointegration is rejected at 5 per cent level. This result gives an indication for the existence of a long-run relationship between real money balances (M2), real income, call money rate and nominal exchange rate.

TABLE 2.3

Long-Run Coefficient of ARDL (2, 0, 0, 2) Dependent Variable $\left(\ln R M d_{t}\right)$

\begin{tabular}{|c|c|c|c|}
\hline Regressors & Coefficient & $\begin{array}{c}\text { Standard } \\
\text { Error }\end{array}$ & t-Ratio \\
\hline Constant & 4.43 & 3.87 & 1.15 \\
\hline $\ln R y_{t}$ & 0.76 & 0.17 & $4.34 * * *$ \\
\hline $\ln E R_{t}$ & 0.97 & 0.06 & $14.91^{* * *}$ \\
\hline$C M R_{t}$ & -0.011 & 0.01 & $-1.70^{*}$ \\
\hline
\end{tabular}

Note: $* * *, * *$ and $*$ show significance level at 1 percent, at 5 percent and at 10 percent significance levels, respectively.

The estimation results provide evidence of the complex dynamics and relatively long effects that seem to exist between real demand for money and its determinants and fulfill the theoretical expectation about their signs. Table 2.3 reveals that real income $\left(R y_{t}\right)$ and foreign exchange rate $\left(E R_{t}\right)$ are the most significant factors of real demand for money in Pakistan where as the significance level of call money rate $\left(C M R_{t}\right)$ is observed at $10 \%$. So overall the test statistics do not point any problem with empirical fitness. The estimation results provide evidence of the complex dynamics and relatively long effects that seem to exist between real demand for money and its determinants along with their signs are Consistent with theoretical postulates.

The coefficient 0.75739 shows that one percent increase in real income leads to over 0.75739 percent increase in real demand for money in long-run. Such significant relation between real demand for money and real income as well as the value of its coefficient is supported by several of 
researchers in the Pakistan and other countries like Ashfaque H. Khan (1994), Mohsen Bahmani-Oskooee (2002), Arshad khan (Winter 2005), Rehman (2005), Mohsen B, Charikleia E (2005), Renani (2007), Samreth, Sovannroeun (2008), Parez et al (2010), Noer Azam Achsani (2010), Nazar Damardeh (2011), Suliman Zakaria Suliman (2011), Prof Nikolaos (2011), Saranya Saranya Raksong (2012).

The coefficient of Call money rate which is inversely elastic with real demand for money in Pakistan shows 0.019830 percent variation in real demand for money as compared to 1 percent change itself. The negative magnitude of call money rate with real demand for money is supported by Mohsen Bahmani-Oskooee (2002), Mohsen B, Charikleia E (2005), Qazi et al ,(2009), Singh, Parakash and Pandey, Manoj K. (2009), Noer Azam Achsani (2010), Nazar Damardeh (2011).

Exchange rate indicates the most significant factor of the model and its positive coefficient on real money balance may be a justified response of depreciation of domestic currency which leads to increase the domestic currency value of foreign assets in terms of M2. M2 as an investment-oriented definition of money which attracts the holders to convert their foreign assets into domestic currency Bahmani-Oskooee and Shabsigh (1996), Mohsen Bahmani-Oskooee (2002), Muhammad Arshad Khan (2005). So the stock of broad money is considered to maintain the share of wealth of a holder invested in domestic currency. The positive relation of nominal exchange rate with real money demand (M1) is anyhow supported by Bradly T. Ewing (1999) who concluded the importance of nominal effective exchange rate as a determinant of money (M1 and M2) function in Chile and found a positive as well as a stable long-run relation of nominal effective exchange rate with real money balances M1.

TABLE 2.4 Error Correction Representation of the Selected ARDL $(2,0,0,2)$ Model Dependant Variable $\Delta$ ln $\left(\boldsymbol{R M d}_{t}\right)$

\begin{tabular}{|l|c|c|c|}
\hline \multicolumn{1}{|c|}{ Regressors } & Coefficient & $\begin{array}{c}\text { Standard } \\
\text { Errors }\end{array}$ & t-Ratio \\
\hline$\Delta L n R M d 1$ & 0.56 & 0.142 & $3.95^{* * *}$ \\
\hline$\Delta L n R y$ & 0.39 & 0.17 & $2.28^{* *}$ \\
\hline$\Delta L n E R$ & 0.50 & 0.17 & $3.02^{* * *}$ \\
\hline$\Delta C M R$ & -0.009 & -0.009 & -1.62 \\
\hline$\Delta C M R 1$ & 0.018702 & 0.006 & $3.16^{* * *}$ \\
\hline$E C M(-1)$ & -0.51550 & 0.14879 & $-3.46^{* * *}$ \\
& & & \\
\hline
\end{tabular}

$R^{2}=0.56$, Adj. $R^{2}=0.44, \mathrm{~F}(6,29)=5.82(0.0)$,

$\mathrm{DW}=2.40$, LM test $=2.52(0.11)$, Norm. test $=$

$1.69(0.45)$,Ramsey $\quad$ Reset test $=0.52(0.60)$,

Hetero $=0.86(0.36)$.

Note: $* * *, * *$ and $*$ show significance

level at 1 percent, at 5 percent and at 10

percent significance levels, respectively.

$\Delta$ LNRMD1 $=$ LNRMD $(-1)-\operatorname{LNRMD}(-2)$

$\Delta \mathrm{LNRY}=\mathrm{LNRY}-\mathrm{LNRY}(-1)$
$\Delta$ LNER $=$ LNER-LNER $(-1)$
$\Delta$ CMR $=$ CMR-CMR $(-1)$
$\Delta$ CMR $1=$ CMR $(-1)-C M R(-2)$

The diagnostic estimations for the short run dynamics of the real demand for money are presented in the upper panel of Table 2.4. The generally specified form of short-run dynamics to examine real demand for money function was firstly introduced by Hendry and Erricson (1991 a, b)).

The table (2.4) shows real income $\left(\Delta \ln R y_{t}\right)$ elasticity is 0.39043 which is significant as reflected by a t-statistics (tratio) of 3.9480. The coefficient 0.39043 shows that one percent increase in real income leads to increase real demand for money by 0.39043 percent in short-run period of time. The elasticity of the variable call money rate is negative 0.0096175 and significantly supports our theoretical expectations and it is also considered an important variable in the previous studies by Qayyum (2000). The coefficient of Call money rate which is inversely elastic with real demand for money in Pakistan shows 0.0096175 percent variation in real demand for money as compared to 1 percent change in itself.

The coefficient of foreign exchange rate (LCU per US dollar) is positive. It shows depreciation of domestic currency by $1 \%$ reacts to decreases the real demand for money (M2) by 0.49895 percent. It means the demand for M1 shifts into M2. It means exchange rate negatively relation with M1 but is positively relation with M2 Dr. Omar Marashdeh (1997).

ECM (-1) presents the convergence of the model towards equilibrium by its negative sign and the value 0.51550 shows real demand for money adjusts to restore 51.5 percent of a disequilibrium from the previous year to the current year and low speed of adjustment indicates a saving element of M2. A long-run consideration of future income and the rates of return stimulate the precautionary saving motive of a resident person Cuthberston and Taylor (1990). This correction speed of adjustment is comparatively more consistent than the finding of other countries such as: 32 percent in Bangladesh Shamim Ahmad (1995), $3.6 \%$ in Malaysia Dr. Omar Marashdeh (1997), 32 percent in Namibia Sylvanus I. Ikhide, 10 percent in Pakistan Qayyum (2005), 6.2 percent in Nigeria Owoye and Onafowora (2007), 26 percent as empirical panel investigation in Asian Pacific countries Abbas Valadkhani, (2008), 20 percent in India Singh, Parakash and Pandey, Manoj K. (2009), 16 percent in Iran (Sharifi, Renani, Hosein (2007), 13 percent in Greece Prof. Nikolaos Dritsakis (2011), 6 percent in China Baharumshah Z. A., Mohd, H. S. and Yol, A.M. (2007), 12 percent in Pakistan Muhammad Arshad Khan (2005), 4.9 percent in Cambodia Samreth, Sovannroeun (2008), 9.2 percent in Pakistan Qazi et al ,(2009), 15 percent in Indonesia from 1990:1 to 2008:3 Noer Azam Achsani (2010).

A microscopic examination of the table indicates that a low coefficient of determination. This can be observed from the value of R-squared 55.5 percent and the adjusted R-squared 44.4 percent. Although there are several findings contain Rsquare less than $50 \%$ in short run dynamics. For example: Bennett McCallum, (1987), Qayyum, (2005), Samreth, Sovannroeun (2008), Singh, Parakash and Pandey, Manoj K., (2009) the value of $\mathrm{R}^{2}$ given in the table 2.4 shows only $44.5 \%$ variation in error correction model (short-run relation equilibrium) is not providing the sufficient performance of the model in short-run causing the economic variables determine 
real demand for money are to be indentified in Pakistan. The table 2.4 reveals that. All the coefficients of the variables are significant in the long-run relationship of the model.

The Durbin Watson statistics which is equal to 2.3967 claims no evidence of serial correlation in the model. The table values: $d_{L}=1.124$ and $d_{U}=1.449$ taking number of observations (n) equal to 38 and number of explanatory variables excluding the constant term $(\mathrm{k})$ as 3 .

We can conclude the value of test statistic lies greater than $d_{U}$ and again is less than $4-d_{U}=2.551$ which clearly indicates the Durbin Watson statistics falls within the range of null hypothesis. So our result assures an insignificant conclusion at $1 \%$ level of significance.

\section{Plot of Cumulative Sum of Squa res of Recursive Residuals}

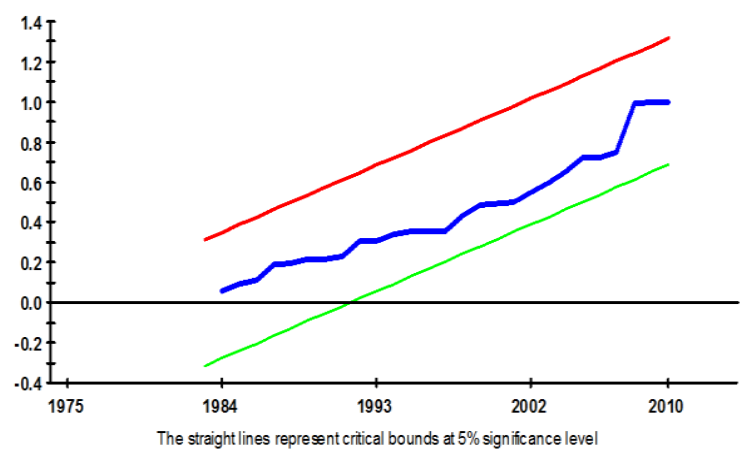

This research paper purposes an estimation of a dynamic demand for money function in Pakistan that could hold a key position for an optimal policy analysis we finally examine how stable the model is reported in the table 2.3 we follow Behmani-Oskooee and Shin (2002) and apply the level of stability tests CUSUM and CUSUMSQ proposed by Brawn et al. (1975). "It is now becoming standard practice to incorporate short-run dynamics in testing for the stability of the long-run parameters of the money demand equation" Olugbenga A. Onafowora (International Business \& Economics Research Journal: Volume 3, Number 8). Once variables are confirmed for a long-run cointegration then the stability of money demand function can be tested. If graphical plot of CUSUM and CUSUMSQ stays within 5\% significance level, then our proposed real demand for money function is said to be a stable function. So incorporating the stability tests using both the CUSUM and CUSUMSQ this paper contain no structural change in the model. The stability confirmation of the proposed model in this paper is comparatively more appropriate than the previous studies. For example: Hossain, A. (1994) in Pakistan, D.V.G. Krishna (1996) in India, Khan and Ali (1997), Qayyum, A. (1998), Qayyum, A. (2001, 2005) in Pakistan, Mohsen B, Charikleia E (2005) in Greece, Samreth, Sovannroeun (2008) in Cambodia, Singh, Parakash and Pandey, Manoj K. (2009) in India, Noer Azam Achsani (2010) in Indonesia in Short-run dynamics and Dr. Pervez Azim (2010) in Pakistan. Anyhow the findings might be indication of real demand for M2 in Pakistan should be a monetary aggregate that State Bank of Pakistan (SBP) should control.

\section{POLICY IMPLICATION OF FINDINGS}

The evidence of an important implications derived from the above findings suggest real income, call money rate (proxy of interest rate) and exchange rate are the important determinants of the demand for money in Pakistan which strongly support the effective alternations of monetary policy as well as the fiscal policy. The improved monetary and fiscal driven changes can rebalance the unfavorable variations in exchange rate hence confidence restoration of the people in Pak-rupee would be assured.

A weak dependency of real money demand on interest rate found in long-run as well as short-run equilibrium of the model contains these implications may play a significant role for reliable banking system in Pakistan that could ensure the productive and trust worthy sources of interest given on public deposits. Whereas the proposed study finds real income is a significant variable in determining the size of composition of the demand for money. We have found an increase in real income both in long-run and in short-run will lead to more significant increase in the real demand for money broadly defined.

An effectual monetary policy conduct requires some very important areas of real demand for money function need more careful investigation. Firstly the stability level of the model must be more improved than of previous studies especially done in Pakistan. The package of different results from the error correction model and the CUSUM and CUSUMSQ tests to examine the stability, witnesses the demand for money function is more stable than Qayyum (1998, 2001and 2005) and Dr. Pervez Azim (2010) in Pakistan. Anyhow as the previous studies on real demand for money in Pakistan rationalize that the political instability, regional disparity of resources and income, weak policy reforms in fiscal expansions, crisis in the balance of payment situation, depreciation of domestic and other changes in the monetary policy front in Pakistan could be the cause of this smaller instability in the money demand function.

Secondly real income is an important determinant of real demand for money and a long-run elastic magnitude of real income contains one percent increase in real income leads to 1.2556 percent increase in real demand for money. On the other hand the significant of this relationship also provides the statistic value of t-test lies out of the critical region. The shortrun dynamics between real income $\left(\Delta \ln R y_{t}\right)$ and real demand for money contains 0.39043 percent elasticity along with its significant reflection presented by a 2.2755 value tstatistics (t-ratio). This specific relation between real demand for money and real income is consistent to economic theory and similar with previous studies in the Pakistan and other countries like Ashfaque H. Khan (1994), Mohsen BahmaniOskooee (2002), Arshad khan (Winter 2005), Rehman (2005), Mohsen B, Charikleia E (2005), Renani (2007), Samreth, Sovannroeun (2008), Parez et al (2010), Noer Azam Achsani (2010), Nazar Damardeh (2011), Suliman Zakaria Suliman (2011), Prof Nikolaos (2011), Saranya Saranya Raksong (2012). The value of short-run and long-run elasticity between real income and real demand for money suggests that the state bank of Pakistan should be very careful for using any policy that influences real income of the people. it can be the cause of rise in inflation in the economy because an increase in real income impacts the real demand for money much more than real income is influenced. 
Thirdly exchange rate is another an important determinant of real demand for money and a long-run elastic magnitude of exchange rate contains one percent increase in exchange rate leads to 0.96791 percent increase in real demand for money. On the other hand the significant of this relationship also provides the statistic value of t-test lies out of the critical region. The short-run dynamics between exchange rate and real demand for money contains 0.49895 percent elasticity along with its significant reflection presented by 3.0167 value t-statistics (t-ratio). This specific relation between real demand for money and exchange rate is consistent to economic theory and similar with previous studies in the Pakistan and other countries like Bahmani-Oskooee and Shabsigh (1996), Mohsen Bahmani-Oskooee (2002), Muhammad Arshad Khan (2005). The value of short-run and long-run elasticity between exchange rate and real demand for money suggests that the state bank of Pakistan should be very careful for using any policy that influences exchange rate. An increase in exchange rate impacts the real demand for money comparatively less than real income is influenced.

Fourthly call money rate (proxy of interest rate) is also an important determinant of real demand for money and a longrun elastic magnitude of real income contains one percent increase in real income leads to -0.2894 percent decrease in real demand for money. On the other hand this relationship is reliable at $10 \%$ level of significance. The short-run dynamics between call money rate and real demand for money contains -0.0096175 percent elasticity along with its significant reflection presented by -1.6215 value $t$-statistics (t-ratio). This specific relation between real demand for money and call money rate is consistent to economic theory and similar with previous studies in the Pakistan and other countries like Mohsen Bahmani-Oskooee (2002), Mohsen B, Charikleia E (2005), Qazi et al ,(2009), Singh, Parakash and Pandey, Manoj K. (2009), Noer Azam Achsani (2010), Nazar Damardeh (2011). The value of short-run and long-run elasticity between call money rate and real demand for money suggests that the state bank of Pakistan should be very careful for using any policy that influences call money rate. An increase in call money rate impacts the real demand for money much less than real income and exchange rate.

Fifthly the restoration speed of the model that converge toward its equilibrium level reveals real demand for money can adjust its restoration $51.5 \%$ of a disequilibrium level from the previous year to the current year and low speed of adjustment indicates a saving element of M2. This speed of adjustment is comparatively more consistent than the finding of other developing countries such as: 32 percent in Bangladesh Shamim Ahmad (1995), 3.6 \% in Malaysia Dr. Omar Marashdeh (1997), 32 percent in Namibia Sylvanus I. Ikhide, 10 percent in Pakistan Qayyum (2005), 6.2 percent in Nigeria Owoye and Onafowora (2007), 26 percent as empirical panel investigation in Asian Pacific countries Abbas Valadkhani, (2008), 20 percent in India Singh, Parakash and Pandey, Manoj K. (2009), 16 percent in Iran (Sharifi, Renani, Hosein (2007), 13 percent in Greece Prof. Nikolaos Dritsakis (2011), 6 percent in China Baharumshah Z. A., Mohd, H. S. and Yol, A.M. (2007), 12 percent in Pakistan Muhammad Arshad Khan (2005), 4.9 percent in Cambodia Samreth, Sovannroeun (2008), 9.2 percent in Pakistan Qazi et al ,(2009), 15 percent in Indonesia from 1990:1 to 2008:3 Noer Azam Achsani (2010).

\section{(VI): CONCLUSION}

In this paper we will develop an econometric model of real demand for money, applying the ARDL approach to cointegration analysis of Pesaran and Shin (1998) and Pesaran et al. (2001) from the time series data for the period 1973 to 2010. The results show that real income (Ry) and foreign exchange rate local currency unit per US dollar (FER) have positive relation with real demand for money (RMd) while call money rate (CMR) negatively associated with real demand for money (RMd). However in a short-run dynamic specification, money demand is found important with the elasticities of real income, exchange rate and call money rate being much smaller in the short-run than in long-run. The stability of our proposed demand for money model has been examined to assure the short run dynamics for long run consistency of parameters applying CUSUM test based on cumulative sum of recursive residuals and CUSUMSQ test is based on squared recursive residuals as initially proposed by Brawn et al (1975). The CUSUM test is plotted against the break points. The estimated coefficients are said to be stable in case if the plot of CUSUM statistic stays within 5\% level of significance. This paper contains no structural change in the model as the case of CUSUMSQ test. However the plot of CUSUM statistics showing the slight touch to the critical value line, presenting the model is minor instable. Anyhow political instability, regional disparity of resources and income, weak policy reforms in fiscal expansions, inappropriate changes in the monetary policy, crisis in the balance of payment situation and depreciation of domestic currency in Pakistan could be the cause of this smaller instability in the money demand function. In the light of the present study we strongly recommend the real demand for M2 is an important monetary aggregate in terms of policy implications of our results, including the suitability of the model than of previous estimations will shed some lights or provide an empirical basis for further study on money demand in Pakistan.

\section{POLICY IMPLICATIONS OF THE FINDINGS}

The evidence of an important implications derived from the above findings suggest gross domestic product growth, financial market development, size of market, public capital stock and the openness of trade are the important determinants of FDI in Pakistan. The finding of the study may contribute in the following areas: firstly the developing countries like Pakistan are unable to reap the optimal benefits of FDI due to the political instability. The optimal fruits of FDI require firm political stability under democracy. Secondly the government should reshape its image in trust worthy frame to restore the size of local firms (size of market). For this very purpose government should deal with the promises which she has made with the investors and should complete all the energy related projects on primarily bases. Thirdly we second the policy implication by Muhammad Arshad Khan (2007) who argues that having a better ability to absorb the positive impact of FDI and promoting economic performance a well developed financial sector can represent a source of comparative advantage for Pakistan. Fourthly the study strongly supports the effective concentration of the international donor agencies like UNO, ADB and IMF and the friend countries of Pakistan on the economic infrastructure reconstruction. It will result in twofold benefit, first is rehabilitation and second is maintaining and uplifting of FDI inflow 2) the same concentration is required by the policy makers to ensure the significant factors while making policies in respect of FDI. Fifthly the government should redefine the 
priorities in favor of FDI that could affect foreign capital more. Iqbal Mahmood (2011) argues for government capabilities must be taken into account while it designs its FDI favorable policies. Sixthly economies like Pakistan should rely upon their own resources rather they finance their economies from other external sources to attain self sufficiency and economic growth.

\section{CONCLUSION}

In this paper we develop an econometric model of foreign direct investment, with application of recent econometric methodology of Auto Regressive Distributed Lag (ARDL) to cointegration analysis of Pesaran and Shin (1998) and Pesaran et al. (2001). The results show that gross domestic product growth rate, financial market development, public capital stock and trade openness have positive relation with FDI while the size of market negatively associated with FDI in short run as well as long run. An annual time series data set over the period 1970 to 2010 is utilized. Recent data techniques are applied to diagnose and check the time series properties of data; later estimation was carried out where Short run and long run elasticities are estimated.

Our results state that capital stock and foreign direct investment are important factors which affect significantly and positively. Our findings are consistent with the findings of Haider Mahmood (2012), Ahmad Ghazali (2010), Dr. Ch. Abdul Rehman (2011), Muhammad Muazzam Mughal (2011), Haider Mahmood (2012)

The stability of our proposed FDI model has been examined to assure the short run dynamics for long run consistency of parameters applying CUSUM test based on cumulative sum of recursive residuals and CUSUMSQ test is based on squared recursive residuals as initially proposed by Brawn et al (1975). The CUSUM test is plotted against the break points. The estimated coefficients are said to be stable in case if the plot of CUSUMSQ statistic stays within 5\% level of significance.

\section{REFERENCE:}

[1] Fisher (1911), The Purchasing Power of Money.

[2] Marshall, Alfred (1923) Money, Credit and Commerce. McMillan and Co.: London.

[3] Keynes, J. M, (1936), The General Theory of Employment Interest and Money. Macmillan, London.

[4] Baumol, W. J., (1952) The Transaction Demand for Cash: An Inventory Theoretic Approach. Quarterly Journal of Economics, 52, pp. 545-556.

[5] Milton Friedman (1959) The Real Demand for Money: Some Theoretical and Empirical Results.

[6] Mundell AR (1963) Capital Mobility and Stabilization Policy under Fixed and Flexible Exchange Rates. Canadian J. Econ. Polit. Sci., 27: 475- 485.

[7] J. B. Ramsey (1969) Tests for Specification Errors in Classical Linear Least Squares Regression Analysis. Journal of the Royal Statistics Society, series B, vol. 31, 1969, pp. 350-371.

[8] Laidler (1973) The Demand for Money Theories, Evidence and Problems (4th Ed). New York Harper Collins College Publishers.

[9] Akhtar, M. A. (1974) The Demand Function for Money in Pakistan. The Pakistan Development Review.
[10] Tower, E. (1975) Money Demand and the Terms of Trade. Weltwirtschafliches Archv, Vol.111, No.4, pp.623-633.

[11] Ehrlich, I. (1977) Capital punishment and deterrence: some further thoughts and additional evidence, $J$. Political Econ. 85(4):741-788.

[12] Mangla, I. U. (1979) An Annual Money Demand Function for Pakistan: Some Further Results. The Pakistan Development Review.

[13] Arango, S. and Nadiri, I.M. (1979), Price Expectations, Foreign Exchange and Interest Rates, and Demand for Money in an Open Economy, Working Paper No. 359, National Bureau of Economic Research (NBER), Cambridge, M.A, June (1979).

[14] Dickey D.A. and Fuller W.A (1979), Distributions of the estimators for autoregressive time series with a unit root Journal of American Statistical Association, 74: 427431.

[15] Khan, A. H. (1980), The Demand for Money in Pakistan: Some Further Results, The Pakistan Development Review.

[16] Dickey, D.A and W.A. Fuller (1981), Likelihood ratio statistics for autoregressive time series with a unit root. Econometrica, 49, pp. 1057-1072.

[17] Arango, S. and Nadiri, I.M. (1981), Demand for Money in Open Economies, Journal of Monetary Economics, Vol.7, No.1, pp. 69-83.

[18] Khan, A. H. (1982), Permanent Income, Inflation Expectations, and the Money Demand Function in Developing Countries, The Pakistan Development Review.

[19] Layson, S. (1983), Homicide and Deterrence: Another view of the Canadian time series evidence Cand, J. Econ. 16:52-73.

[20] Nisar, S., and N. Aslam (1983), The Demand for Money and the Terms Structure of Interest Rates in Pakistan, The Pakistan Development Review.

[21] Bennettt T. McCallum, (1987): Theoretical Analysis of the Real Demand for Money.

[22] Phillips, P.C.B. and P. Perron (1988) Testing for a Unit Root in Time Series Regression, Biometrika, 75, 335346.

[23] Arize, A.C. (1989), An Econometric Investigation of Money Demand Behaviour in Four Asian Developing Economies, International Economic Journal, Vol.3, pp.79-93.

[24] Bennettt T. McCallum (1989), Monetary economics: theory and policy, Mcmillan Publishing Company, 866 Third Avenue, New York, New York10022.

[25] Ahmad, M., and A. H. Khan (1990), A Reexamination of the Stability of the Demand for Money in Pakistan. Journal of Macroeconomics.

[26] Cuthberston, K. and Taylor, M.P. (1990) Money Demand, Expectations, and the Forward-looking Model, Journal of Policy Modelling, Vol.12, No.1, pp. 289-315. 
[27] Bahmani M, Malixi M (1991) Exchange rate sensitivity of the demand for money in developing countries. App. Econ., 23(8): 1377-1383.

[28] Simmons, R (1992) An error-correction approach to demand for money in five African developing countries, Journal of Economic Studies 19(1), 29-48.

[29] McNown, R., and M. Wallace (1992), Cointegration Tests of a Long-run Relation between Money Demand and the Effective Exchange Rate, Journal of International Money and Finance, Vol.11, pp. 107-114.

[30] Hossain, A. (1994) The Search for a Stable Money Demand Function in Pakistan: An Application of the Method of Cointegration. The Pakistan Development Review33:4.

[31] Bahmani-Oskooee, M. and H.J. Rhree (1994), Long-run Elasticities of the Demand for Money in Korea: Evidence from Cointegration Analysis, International Economic Journal, Vol.8, No.2, pp.83-93.

[32] Z. Anusic (1994), The Determinants of Money Demand in Croatia and Simulation of the Post-Stabilization Period, Croatian Economic Survey, No. 2, pp. 85-120.

[33] Ashfaque H. Khan (1994), Financial Liberalisation and the Demand for Money in Pakistan, The Pakistan Development Review, 3:4 Part II (winter 1994) pp. 9971010.

[34] Metin, K. (1994), Modelling the Demand for Narrow Money in Turkey, METU Studies in Development, 21/2, 231-256.

[35] Lee, T.H. and K.J. Chung (1995), Further Results of the Long-run Demand for Money in Korea, International Economic Journal, Vol.9, Autumn, pp. 103-113.

[36] Choudhry, T. (1995), "High Inflation Rates and the Long-Run Money Demand Function: Evidence from Cointegration Tests", Journal of Macroeconomics, 17/1, $77-91$

[37] Scott Hendry, (1995) Long-Run Demand for M1.

[38] Kogar (1995), Cointegration Test for Money Demand the Case for Turkey and Israel, CBRT Research Department Discussion Paper, No: 9514, May, 1-18.

[39] D.V.G. Krishna, (1996): An Empirical Analysis of Demand for Money in India (1969-1990).

[40] MacKinnon, James G. (1996) Numerical Distribution Functions for Unit Root and Cointegration Tests, Journal of Applied Econometrics, 11, 601-618.

[41] Bahmani-Oskooee, M. (1996) The Black Market Exchange Rate and Demand for Money in Iran. Journal of Macroeconomics, Vol.18, pp.171-176.

[42] Pesaran, M. H., Y. Shin and R. J. Smith (1996) Testing for the 'Existence of a Long-run Relationship. Faculty of Economics, University of Cambridge, Cambridge Working Papers in Economics 9622.

[43] Agenor, P.R. and M. Khan (1996) Foreign currency deposits and the demand for money in developing countries, Journal of Development Economics 50(1), 101-118.
[44] Pesaran, M. H. and B. Pesaran (1997) MicroFit4.0: Interactive Econometric Analysis. Oxford: Oxford University Press.

[45] Dekle, R. and Pradhan, M. (1997) Financial Liberalization and Money Demand in ASEAN Countries: Implications for Monetary Policy, IMF Working Paper 97/36, 1-38.

[46] Dr. Omar Marashdeh (1997) The Demand for Money in an Open Economy: the Case of Malaysia. Southern Finance Association Annual Meeting, Baltimore, Maryland, USA.

[47] Pesaran, M. H. and Y. Shin (1999) An autoregressive distributive lag modeling approach to cointegration analysis. In Storm, S. (ed.), Econometrics and Economic Theory in 20 $0^{\text {th }}$ Century: The Ragnar Frisch Centennial Symposium. Cambridge: Cambridge University Press.

[48] Khan, A. H., and S. S. Ali (1997) The Demand for Money in Pakistan: An Application of Cointegration and Error Correction Modeling. Savings and Development.

[49] Treichel, V. (1997) "Broad Money Demand and Monetary Policy in Tunisia", IMF Working Paper 97/22, $1-27$.

[50] Eitrheim, Æ. (1998) The Demand for Broad Money in Norway, 1969-1993, Empirical Economics, 23, 339-354.

[51] Vega, J.L. (1998) Money Demand Stability: Evidence from Spain, Empirical Economics, 23, 387-400.

[52] Ericsson, N. R. and Sharma, S. (1998) Broad Money Demand and Financial Liberalization in Greece. Empirical Economics, 23, 417-436.

[53] Qayyum, A. (1994-98) Error Correction Model of Demand for Money in Pakistan. Kashmir Economic Review 1-2.

[54] V. Sonje (1999) Esej o monetarnim eksperimentima, ili: kako izabrati monetarni rezim u kasnoj fazi tranzicije, Economic Trends and Economic Policy, Vol. 9, No. 74, pp. 41-72.

[55] Subramanian S. Sriram, (1999) Survey of Literature on Real Demand for Money :Theoretical \& Empirical Work with Special Reference to Error-Correction Model.

[56] Bradley T. Ewing and James E. Payne (1999) Long-run Money Demand in Chile, Journal Of Economic Development, Volume 24, Number 2, December 1999.

[57] Qayyum, A. (2000), Demand for Real Money Balances by the Business Sector: An Econometric Investigation, The Development Review, Pakistan Institute of Development Economics, vol. 39(4), pages 857-873.

[58] Christopher Adam (2000) The Transactions Demand for Money in Chile, University of Oxford, UK, Revised: September 2000.

[59] A. Babić (2000), The monthly Transaction Money Demand in Croatia, Working paper, Croatian National Bank, 2000, pp. 1-46.

[60] Civcir (2000), Broad Money Demand, Financial Liberalization and Currency Substitution in Turkey, ERF Seventh Annual Conference Proceedings, attainable from http://www.erf.org.eg. 
[61] Egoumé-Bossogo, P. (2000) Money Demand in Guyana, IMF Working Paper, June.

[62] Pesaran, M. H., Y. Shin and R. J. Smith (2001), Bounds testing Approaches to the analysis of level relationships. Journal of Applied Economics, Volume 16, pp. 289-326.

[63] Nachega, J.C. (2001), A Cointegration Analysis of Broad Money Demand in Cameroon, IMF Working Paper 01/26, 1-39.

[64] Kannapiran C. A. (2001), Stability of Money Demand and Monetary Policy in Papua New Guinea (PNG): An Error Correction Model Analysis, International Economic Journal, Vol. 15, No. 3, Autumn, 73-83.

[65] Cuthbertson, K. and D. Bredin (2001), Money Demand in the Czech Republic since Transition, January (http://www.centralbank.ie/documents/earp/3RT01.pdf).

[66] Qayyum, A. (2001) Sectoral Analysis of the Demand for Real Money Balances in Pakistan. Pakistan Development Review40: 4Part II (Winter 2001) pp. 953-966.

[67] Bahmani-Oskooee, M. and A. Techaratanchai (2001), Currency Substitution in Thailand, Journal of Policy Modelling, Vol.23, No.2, pp.141-145.

[68] Alkiswani M., (2001), The Demand for Money in Syria: An Error correction Model and Cointegration Approach, Journal of Damascus University, Vol. 17, No.1.

[69] Cluadia M. Buch, (2001), "Money demand in Hungary and Poland", Applied Economics, 33, 989-999.

[70] Mutluer, D. and Yasemin, B. (2002), Modeling the Turkish Broad Money Demand, Central Bank Review 2, 55-75.

[71] Hafeez ur Rehman and Imtiaz Ahmed (2002) Impact Of Monetary Policy On Monetary Assets In Pakistan A Money Multiplier Approach (1980-81 to 1999-2000), Pakistan Economic and Social Review Volume XL, No. 2 (Winter 2002), pp. 199-208.

[72] Mohsen Bahmani-Oskooee (2002), Long-Run Demand for Money in Hong Kong: An Application of the ARDL Model, International Journal of Business and Economics, 2002, Vol. 1, No. 2, 147-155.

[73] Kontolemis, Z. G. (2002), Money Demand in the Euro Area: Where Do We Stand (Today)?, IMF Working Paper 02/185, 1-30.

[74] Abbas Valadkhani, (2002) Long and Short run Determinants of the Real Demand for Money in New Zealand: a Cointegration Analysis.

[75] Hsiu - Yun Lee, (2002) Pitfalls in using Granger causality tests to find an engine of growth.

[76] Jae-Kwang Hwang (2002) The Demand for Money in Korea: Evidence from the Cointegration Test, (JEL E41); Int'l Advances in Econ. Res., 8(3): pp. 188-195.

[77] Abbas Valadkhani and Mohammad Alauddin, (2003), "Demand for M2 in Developing Countries: An Empirical Panel Investigation", Queensland University of Technology, School of economics and Finance, Dicussion Paper No. 149.

[78] Harb, Nasri, (2003), Money Demand Function: Heterogeneous Panel Application, Unpublished Paper, UAE University.
[79] Akınc1, Ö. (2003), Modeling the Demand for Currency Issued in Turkey, Central Bank Review 1, 1-25.

[80] N. Erjavec, and B. Cota (2003), Macroeconomic Granger causal dynamics in Croatia: Evidence based on vector error-correction modeling analysis, Economic Review, Vol .54, No. 1-2, pp. 139-156.

[81] Altınkemer, M. (2004), Importance of Base Money Even When Inflation Targeting, CBRT Research Department WorkingPaper, No. 04/04.

[82] Ouattara, Bazoumana (2004), Modeling the Long Run Determinants of Private Investment in Senegal CREDIT, University of Nottingham.

[83] Al-Zu'bi B., Khalid Saw'I, (2004), Demand for Money in Jordan, Dirasat, Administrative Science, Vol.31, No. 1.

[84] Qayyum, A. (2005) Modelling the Real Demand for Money in Pakistan.

[85] Tahir Mehmood (2005) Relationship Among Money, Interest Rate, Price and Output Evidence from Pakistan.

[86] Shamim Ahmad and Md. Ezazul Islam (2005) Demand for Money in Bangladesh: A Cointegration Analysis, the Bangladesh Development Studies Vol. XXXI, MarchJune 2005, Nos. $1 \& 2$.

[87] Reza (2005) Stability of the Demand for Real Narrow Money in Indonesia.

[88] Mohsen B, Charikleia E (2005) How Stable is the Demand for Money in Greece. Int. Econ. J., 19(3): 461472 .

[89] Abbas Valadkhani (2005) Modeling Demand for Broad Money in Australia.

[90] Nina, (2005) Determinants of Inflation in Ukraine: Cointegration Approach.

[91] Muhammad Arshad Khan, Muhammad Zabir Shahid (Winter 2005), The Exchange rates and monetary dynamics in Pakistan: An Autoregressive Distributive Lag (ARDL) Approach, Lahore Journal of Economics, Volume 10: pp. 87-99.

[92] Shamim Ahmad, (2005) Real Demand for Money in Bangladesh: A Cointegration Analysis.

[93] Cem SAATÇIOGLU (2005) The Turkish Broad Money Demand, Istanbul Ticaret Üniversitesi Sosyal Bilimler Dergisi Yll:4 Sayl:7 Bahar 2005/1 s.139-165.

[94] Halicioglu, Ferda and Ugur, Mehmet (2005) On stability of the demand for money in a developing OECD country: the case of Turkey", Global Business and Economics Review, 7(2-3): 203-213.

[95] Akinlo, A. Enisan (2006) The Stability of Money Demand in Nigeria: An autoregressive distributed lag approach, Journal of Policy Modeling, 28(4): 445-452.

[96] Canova, Luciano (2006), Estimating demand for money in Jamaica, MPRA Paper No. 1023, posted 07. November 2007 / 01:29.

[97] Zakir, H., H. Awan, I. Hussain, M. Farhan and I. Haq (2006), Demand for Money in Pakistan, International Research Journal of Finance and Economics, 5: 209-18. 
[98] Aaron Mehrotra (2006), Demand for Money in Transition: Evidence from China's Disinflation, Transition (BOFIT), PO Box 160, FI-00101 Helsinki, Finland. Email: aaron.mehrotra@bof.fi.

[99] Mohsen, (2007) How Stable the Real Demand for Money in China?

[100] Rao, B. Bhaskara and Kumar, Saten (2007), Cointegration, structural breaks and the demand for money in Bangladesh, MPRA Paper No. 1546, posted 07. November 2007 / 01:50.

[101] Baharumshah Z. A., Mohd, H. S. and Yol, A.M. (2007) Stock prices and Demand for Money in China: New Evidence. Journal of International Financial Markets, Institutions and Money, 19, 171-187.

[102] Aziz KUTLAR (2007), Cointegration Analysis Of Money Demand In Turkey, Sosyal Bilimler Dergisi Sayı: 17.

[103] Sharifi-Renani, (2007) Demand for Money in Iran: An ARDL Approach.

[104] Owoye, O. and Onafowora, O.A. (2007). M2 Targeting, Money Demand, and Real GDP

Growth in Nigeria: Do Rules Apply? Journal of Business and Public Affairs, 1(2), 1-20.

[105] Hsing, Y (2007), Currency Substitution, Capital Mobility and Functional Forms of Money Demand in Pakistan, The Lahore Journal of Economics.Vol,12 .3548

[106] Mahedhiran Nair, Muthi Samudram and Santha Vaithilingam, (2008) Malaysian Money Demand Function Revisited: The ARDL Approach.

[107] Abbas Valadkhani (2008), Long- and Short-Run Determinants of the Demand for Money in the AsianPacific Countries: An Empirical Panel Investigation, Annals Of Economics And Finance 9-1, 77-90 (2008).

[108] Inoue T, Shigeyuki H (2008) An Empirical Analysis of the Money Demand Function in India, Institute of Developing Economies Discussion Paper No. 166, September (2008). 166: 1-34.

[109] Samreth, Sovannroeun (2008) Estimating Money Demand Function in Cambodia: ARDL Approach, MPRA Paper No. 16274.

[110] Salvatore CAPASSO, (2008) Testing for Stability for Money of Money Demand in Italy: Has the Euro Influenced the Monetary Transmission Mechanism?

[111] Samreth, Sovannroeun (2008) Estimating Demand for Money Approach in Cambodia: An ARDL Approach, MPRA Munich Personal RePEc Archive.

[112] Long, Dara. and Sovannroeun Samreth (2008), The Monetary Model of Exchange Rate: Evidence from the Philippines Using ARDL Approach, Economics Bulletin, $1-12$.

[113] Qazi et al, (2009) Relationship between Stock Prices, Exchange rate and Real Demand for Money in Pakistan.

[114] Rao, B. B. and Gazi Hassan (2009), Determinants of the Long Run Growth Rate of Bangladesh: An ARDL Approach, MPRA Paper No. 14972.
[115] Singh, Parakash and Pandey Manoj K, (March 2009) Structural Break, Stability and Demand for Money in India. MPRA Paper No. 1542, posted 26. May 2009.

[116] Gbadebo Olusegun Odularu, (2009) Modeling the impact of financial innovation on the Real Demand for Money in Nigeria.

[117] Han Y, Pei-Tha G (2009), An Empirical Analysis of the Money Demand Function in ASEAN-5, Int. Res. J. Financ. Econ., 33: 168-178.

[118] Baharumshah, Ahmad Zubaidi, Siti Hamizah Mohd and A. Mansur M. Masih (2009), The Stability of Money Demand in China: Evidence from the ARDL model, Economic Systems, 33(3): 231-244.

[119] B. Skrabic, and N. Tomic-Plazibat (2009) Evidence of the Long-run Equilibrium between Money Demand Determinants in Croatia, World Academy of Science, Engineering and Technology 492009

[120] Jude (2010) Cointegration and Structural Breaks in Nigerian Long Money Demand Function.

[121] Dr. Pervez Azim (2010) Demand for Money in Pakistan: an Ardle Approach.

[122] Noer Azam Achsani (2010) Stability of Money Demand in an Emerging Market Economy: An Error Correction and ARDL Model for Indonesia, Research Journal of International Studies - Issue 13 (March, 2010).

[123] S. P. Jayasooria (2010) Dynamic modeling of stability of money demand and minimum wages, Journal of Economics and International Finance Vol. 2(10), pp 221-230.

[124] Muhammad Ilyas (2010) Determinants of Manufacturing Value Added in Pakistan: An application of Bounds Testing Approach to Cointegration, Pakistan Economic and Social Review, Volume 48, No. 2 (Winter 2010), pp. 209-223.

[125] Haroon Sarwar, Zakir Hussain And Masood Sarwar (2010) Money Demand Function For Pakistan (Divisia Approach), Pakistan Economic and Social Review Volume 48, No. 1 (Summer 2010), pp. 1-20.

[126] Olungbenga A. Onafowara, Structural Adjustment and Stability of the Nigerian Money Demand Function. (International Business \& Economics Research Journal: Volume 3, Number 8).

[127] Christopher S. Adam (2011) The Real Demand for Money in Tanzania, Working paper 11_0336, May 2011.

[128] Suliman Zakaria Suliman (2011) An econometric analysis of money demand function in Sudan, 1960 to 2010, Journal of Economics and International Finance Vol. 3(16), pp. 793-800.

[129] Prof. Nikolaos Dritsakis, (2011) Demand for Money in Hungary: An ARDL Approach.

[130] Matteo Mogliani (2011) Monetary Disorder and Financial Regimes the Real Demand for Money in Argentina 1900-2006.

[131] Arqam AL-Rabbaie (2011), Modeling Financial Innovation in the Demand for Money using Structural Time Series Approach: The Case of the US, 
International Research Journal of Finance and Economics ISSN 1450-2887 Issue 72 (2011)

[132] Jafar Haghighat (2011), Real Demand Money, Income, and Interest Rates in Iran: Is There a Long-Run Stable Relation?, World Journal of Social Sciences, Vol. 1. No. 2. May 2011 Pp. 95 - 107

[133] Muhammad Aijaz Rasheed (2011) Relationship between Monetary and Real Variables: Pakistan's experience 1972-2008.

[134] Jihad Daghar (2011) On the Stability of Money Demand in Ghana: A Bounds Testing Approach

[135] Nazar Dahmardeh and Hamid Raza Izadi (2011) Demand for Money in Iran by Auto Regressive Distributive Lag Approach.

[136] Suliman Zakaria Suliman (2011) An econometric analysis of money demand function in Sudan, 1960 to 2010, Journal of Economics and International Finance Vol. 3(16), pp. 793-800, 22.
[137] Saten Kumar, Don J. Webber and Scott Fargher "Money Demand Stability: A Case Study of Nigeria".

[138] Yamden Pandok Bitrus (2011) Demand for Money in Nigeria, European Journal of Business and Management, Vol 3, No.6, 2011.

[139] Dr. AL-Abdulrazag Bashier (2011), The Money Demand Function for Jordan: An Empirical Investigation, International Journal of Business and Social Science, Vol. 2 No. 5; [Special Issue -March 2011].

[140] Saranya Raksong (2012) The Money Demand Behavior Under The Inflation Targetting Framework In Thailand, International Research Journal of Finance And Economics, ISSN 1450-2887 Issue 84 (2012), (c) Euro Journals Publishing, Inc. 2012. 